\title{
فعالية استفدام الفيديو التعليهى فى تنمية المفاهيم والمهارات الأساسية فى رسم المانيكان الرجالى التعليمى لدى طلاب الفرقة الثانية شعبة الملابس الجاهزة
}

THE EFFECTIVENESS OF EMPLOYING INSTRUCTIONAL VIDEO IN THE DEVELOPING CONCEPTS \& BASIC SKILLS IN INSTRUCTIONAL MEN'S MANNEQUIN DRAWING OF THE SECOND GRADE STUDENTS READY-MADE CLOTHES BRANCH
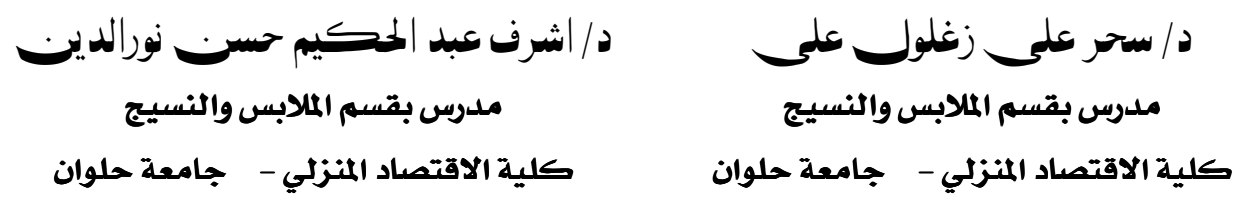
فعالية استخدام الفيديو التعليمي في تنمية المفاهيم والمهارات الأساسية في رسميم المانيكان الرجالي التعليهي لدى طلاب الفرقة الثانية شعبة الملابس الجاهزة

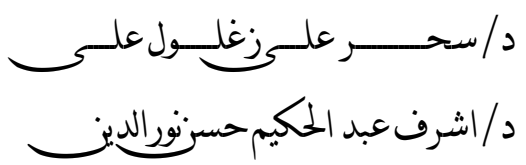

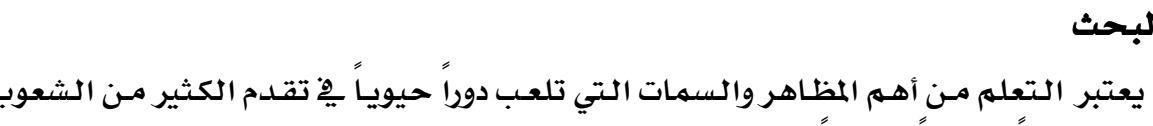

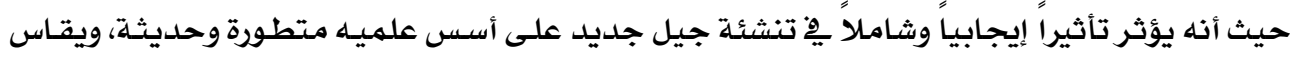

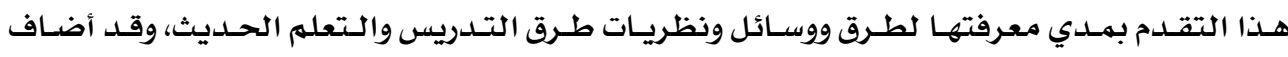

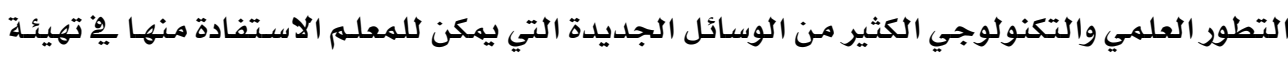

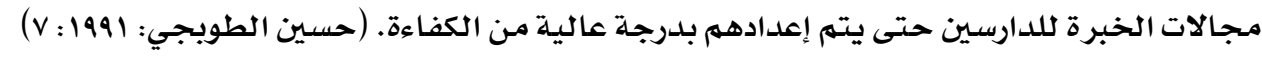

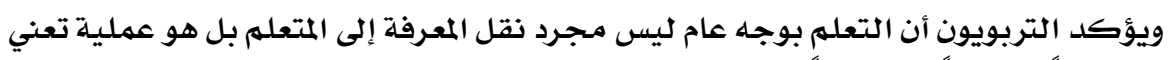

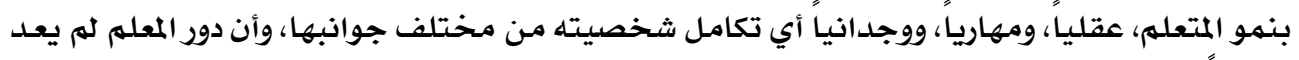

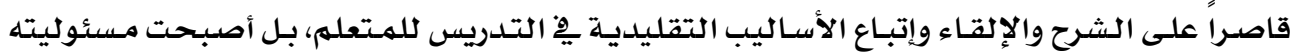

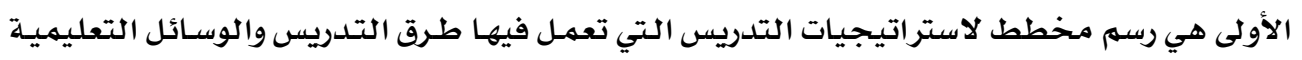

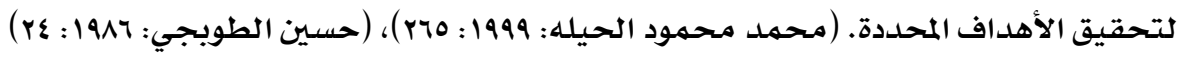

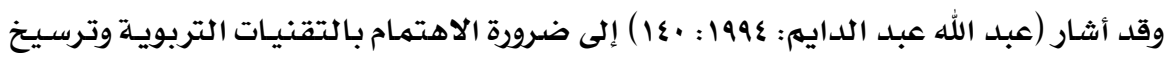

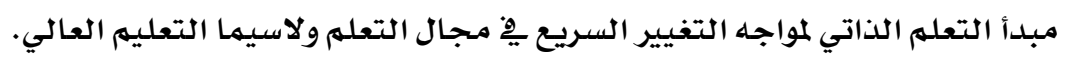

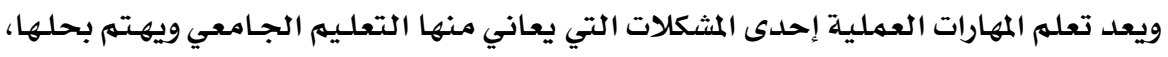

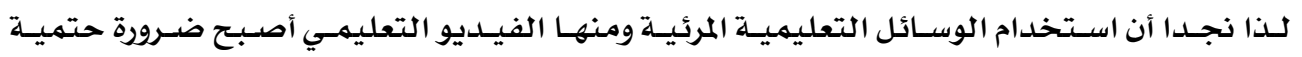

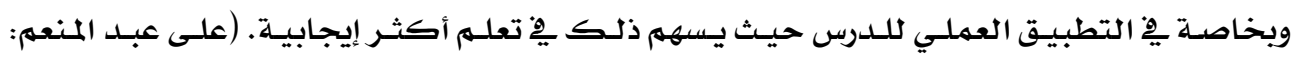

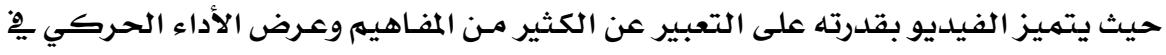

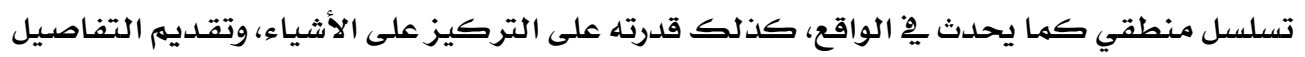

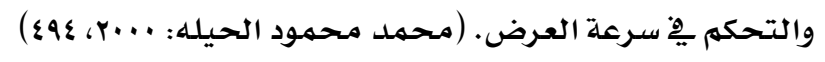

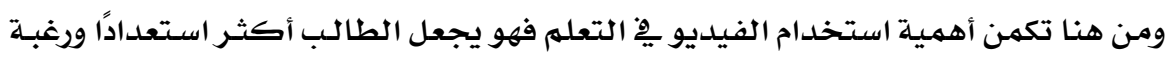

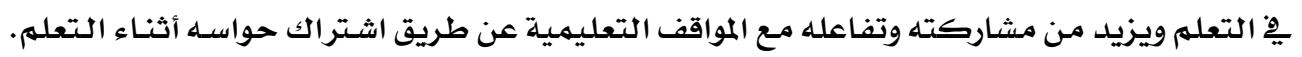

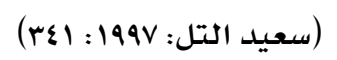

وتعتبر الدراسات التي استخدمت الفيديو التعليمي يِّ التعلم نقله هامة للتطوير والإصـاح التحاح

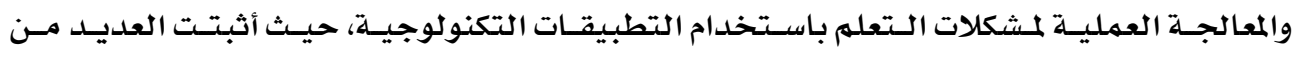

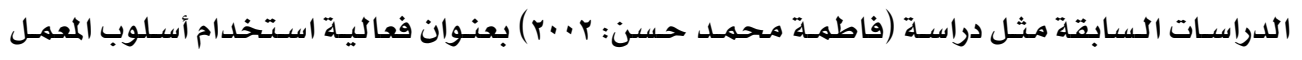




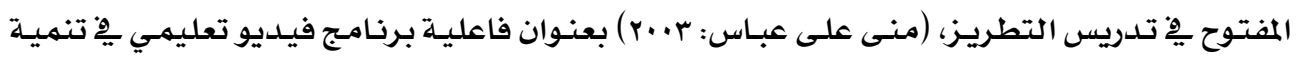

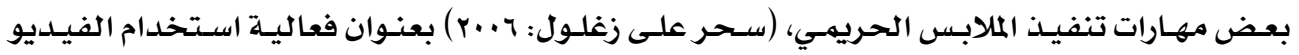

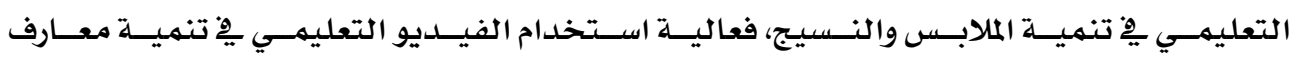
ومهارات الطلاب.

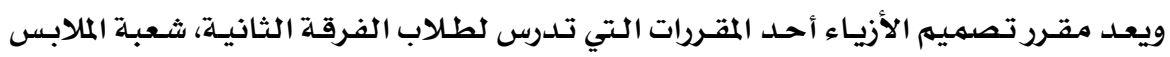

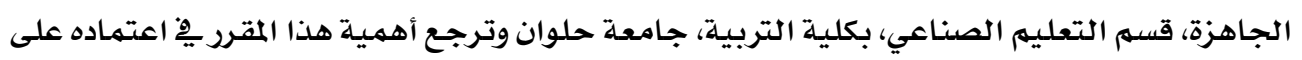

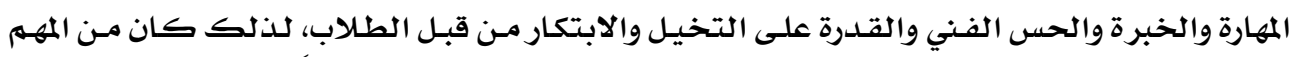

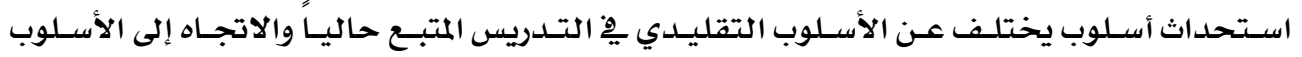

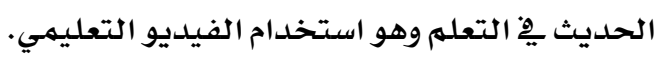
مشكلة البحث:

يمكن صياغة مشكلة البحث بِ التساؤلات الآتية:

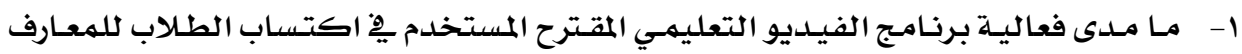
المتضمنـة بـه

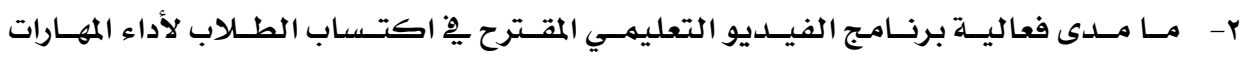

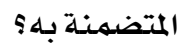

r- ما آراء الطلاب نحو استخدام برنامـج الفيديو التعليمي المقترح كوسيلة للتعله؟ أهمية البحث:

ترجـع أهميـة البحثث ِِِ أنه:

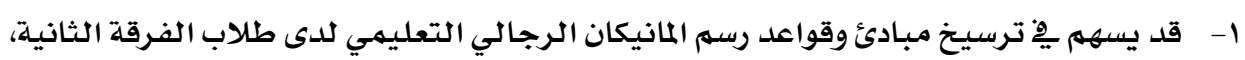

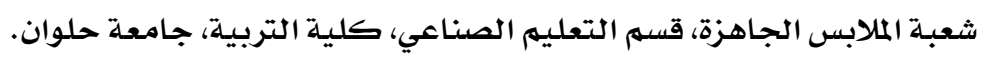

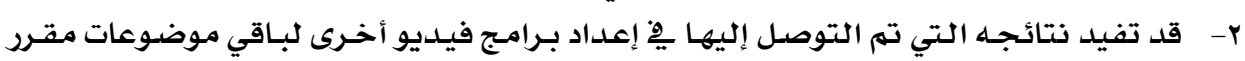

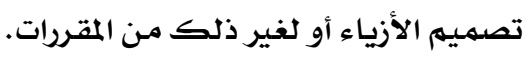

هدف البحث:

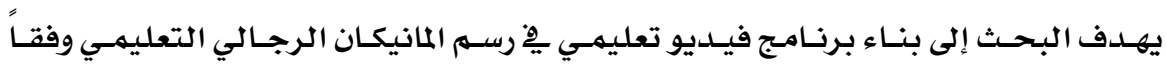

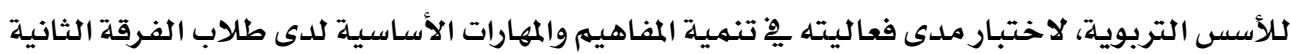

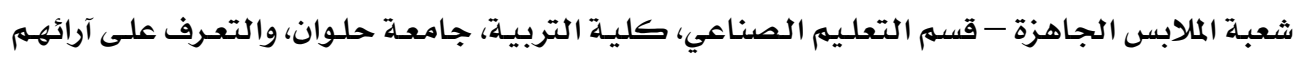

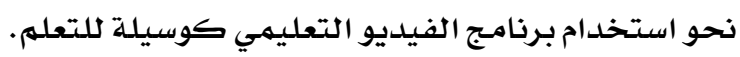
إجراءات البحث:

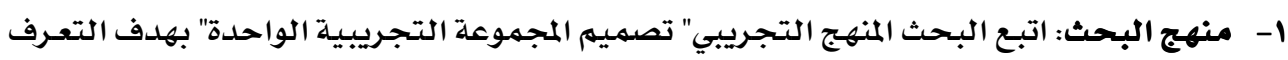

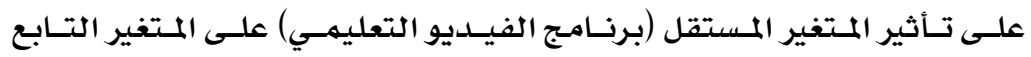
(المفاهيه، المهارات، آراء الطلابر الميتر). 
r - حدود البحث: تقتصر حلدود البحث على:

أ- - دراسـة :-

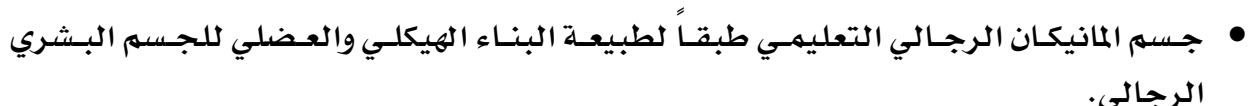
• رسهم المانيكان الرجالي التعليمي المواجه بأوضاع حركية مختلفة.

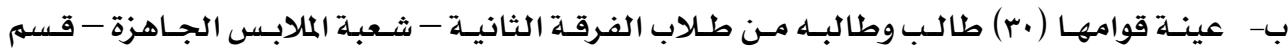
التعليم الصناعي - كلية التربية - جامعلة حلوان.

$$
\begin{aligned}
& \text { r- أدوات البحث: تكونت أدوات البحث مـن } \\
& \text { أ- برنامـج الفيديو التعليهي المقترح. }
\end{aligned}
$$

ب- أدوات تقويم البر نامج (الاختبـار المعريف، بطاقة الملاحظة، استبيان أراء الطلاب). • خطوات أجراء البحث: تشمل خطوات أجراء البحث على محاور رئيسية المحور الأول: يتضمن

ا- الإطلاع على الدراسات السابقة وتحديد اتجاهاتها وأوجـه الاستفادة منها . r- تحديد محاور بناء "برنامـج الفيديو التعليهي المقترح" . المحور الثاني: يتضمن

$$
\text { ا- بناء برنامـج الفيديو التعليمي وفقاً لكلأسس التربوية. }
$$

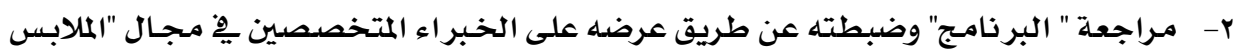

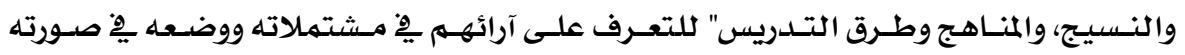

$$
\text { النهائية. }
$$

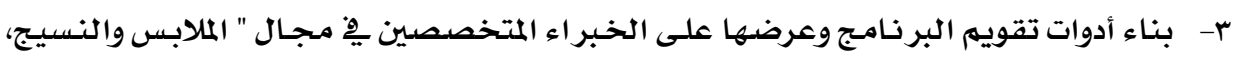

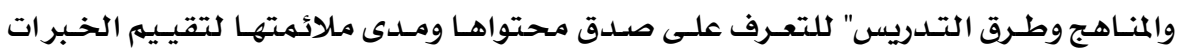

$$
\text { التعليمية. }
$$

المحور الثالث: يتضمن إجراءات الدراسـة الاستطلاعية عن طريق تطبيق البر نامـج وأدوات تقويهـه على الـى

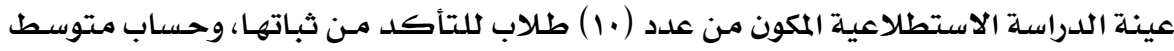

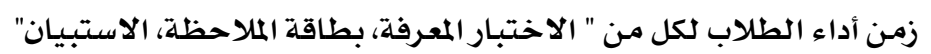

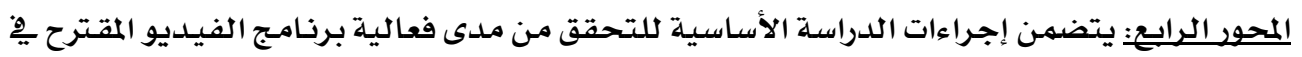

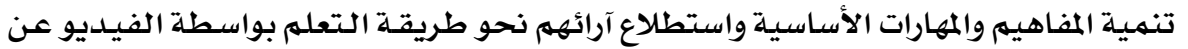
طريق تطبيق:

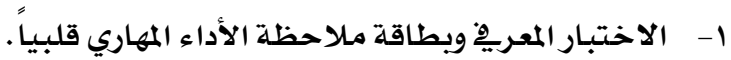

$$
\text { r- برنامـج الفيديو التعليمي. }
$$




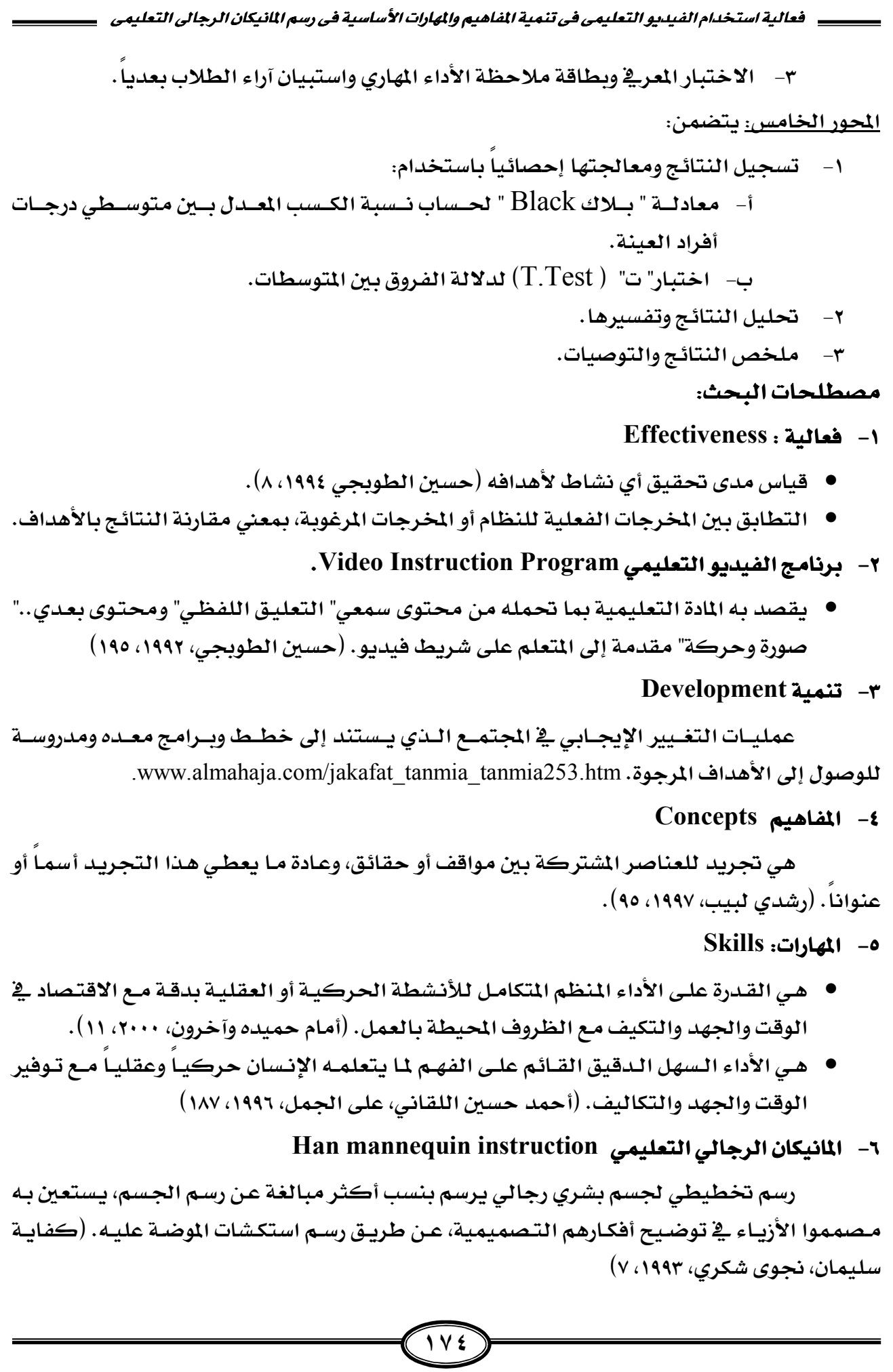


Ready Madecdothes Branch شعبة الملابس الجاهزة -V أحلد شعب قسم التعليم الصناعي بكليـة التربيـة، جامعـة حلـوان، يـدرس بها الطلاب مقررات

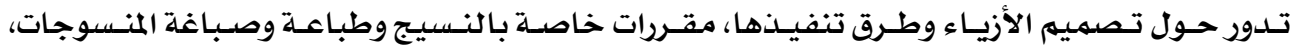

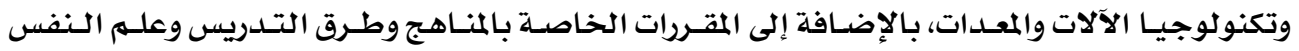

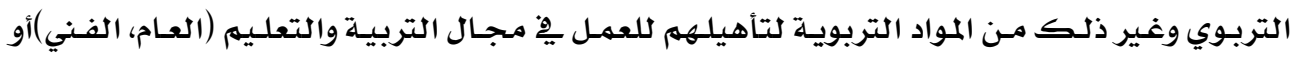

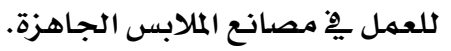
الدراسات السابقة:

$$
\text { تم تقسيهها إلى محورين كالآتي: }
$$

المحور الأول: دراسات تناولت رسهم المانيكان التعليمي.

المحور الثاني: دراسات تناولت استخدام الفيديو التعليمي يِّ مجال الملابس والنسيج. أولاً: دراسات المحور الأول:

1- دراسة " كفاية سليمان، نجوي ثكري" ( • (199).

بعنـوان : فاعليـة اسـتخدام أسـلوب البر مـجـة يِّ تعلـم رســم الجـسم الأسـاسـي للموضــة" المانيكان".

هدفت الدراسـة إلى إدخال أسلوب البر مجة يِّ تدريس وحلده رسهم " المانيكان النسائي" لطسلاب

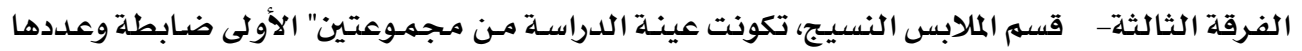

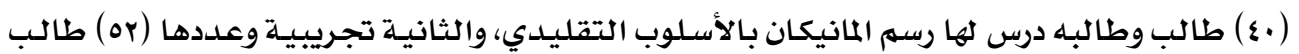

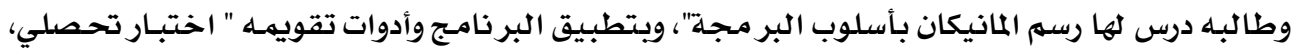

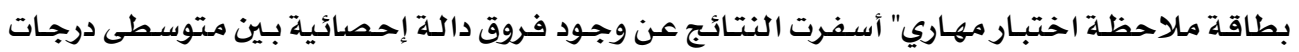

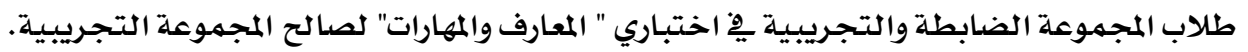

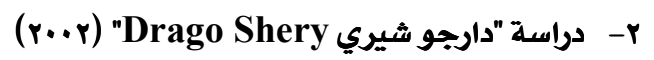

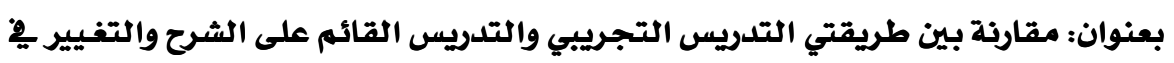

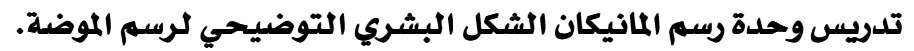
هدفت الدراسـة إلى اختبار مدى فعالية طريقتي " التدريس التجريبي والتدريس القـائم على

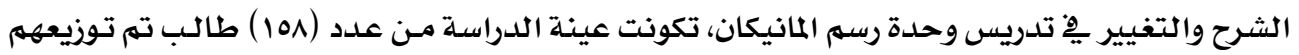

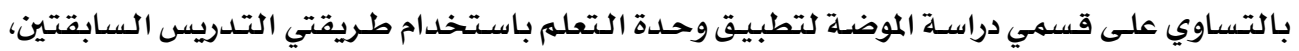
وبتطبيق الوحدة وأدوات تقويهها " اختبار تحصيلي، اختبـار مهاري، بطاقة ملاحظة مقياس الاتجاهـات

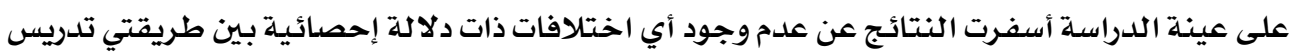




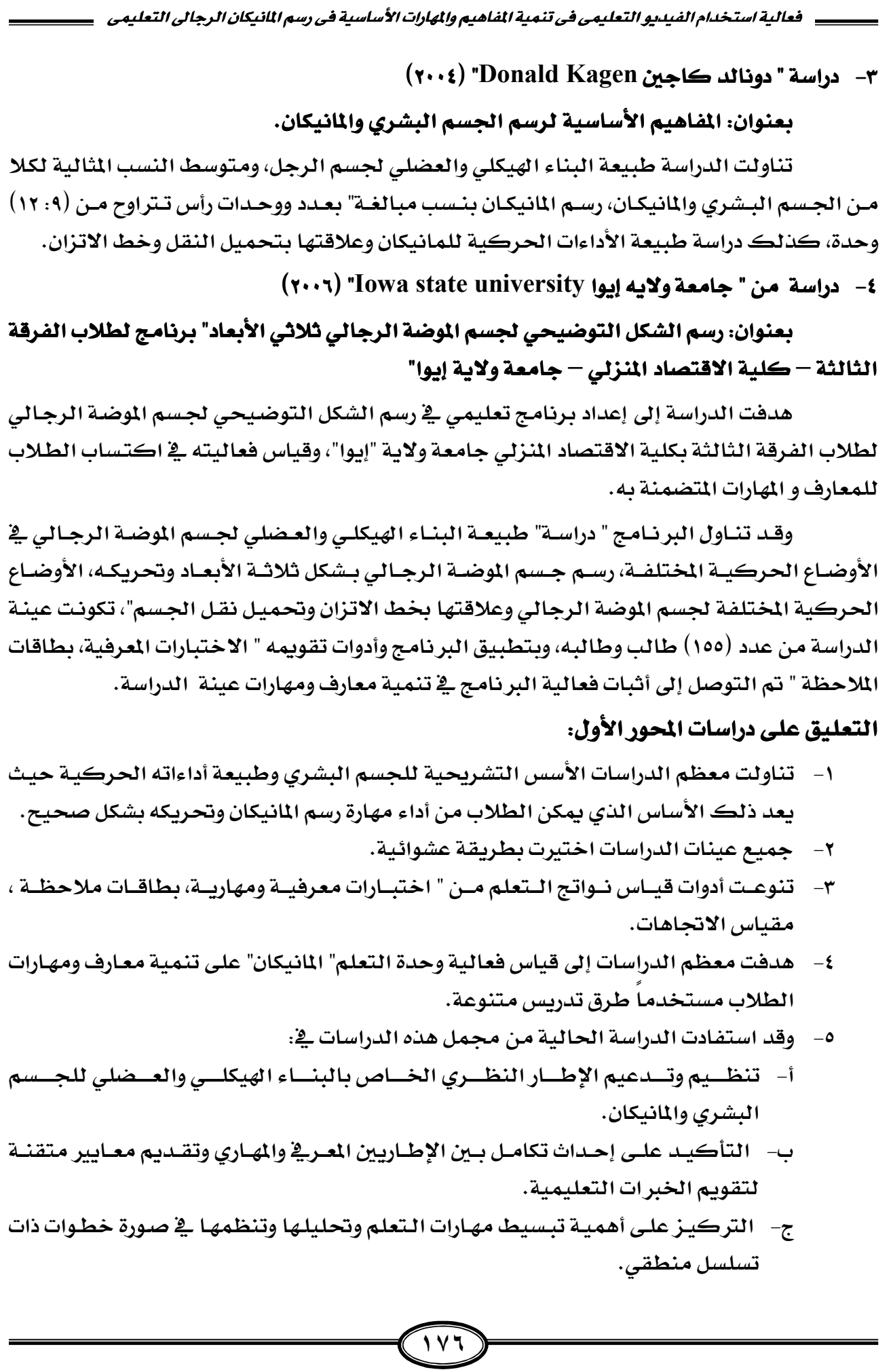




\section{ثانياً: دراسات المحور الثاني: \\ 1- دراسة " فاطمة محمد حسن" (r... (r)}

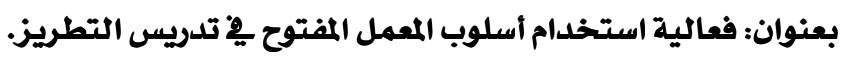

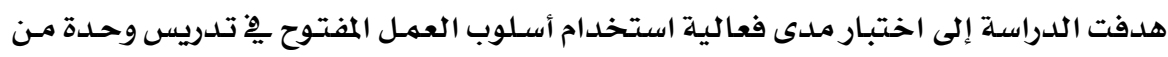

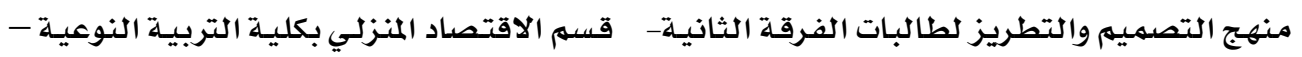

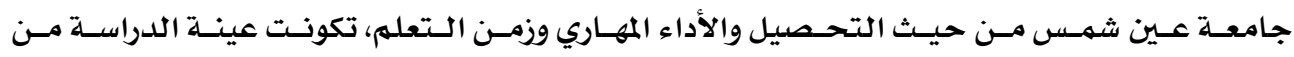

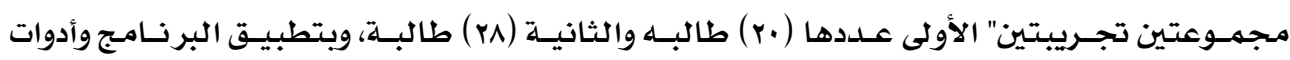

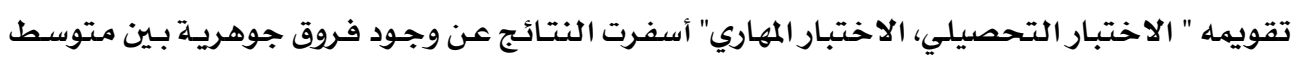

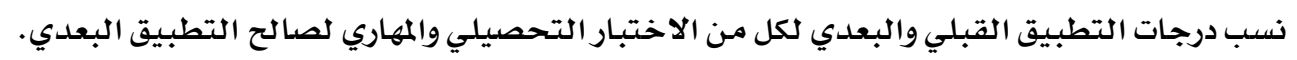

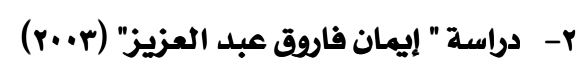

\section{بعنوان: فاعلية برنامج فيديو تعليمي يِّ تنمية مهارات تنفيذ الملابس.}

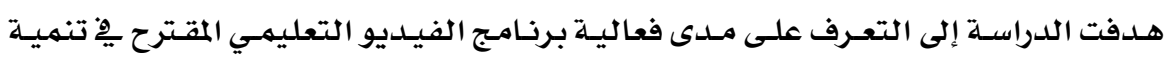

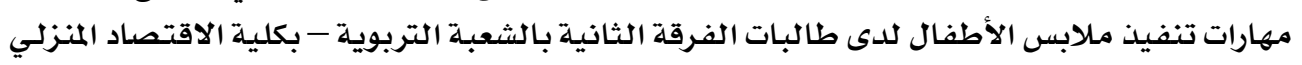

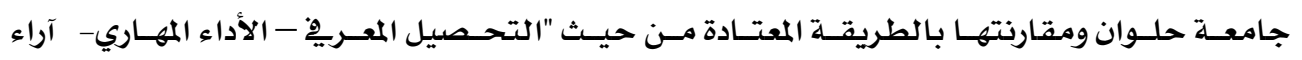

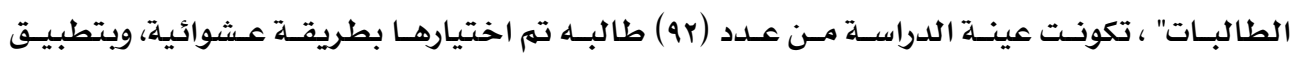

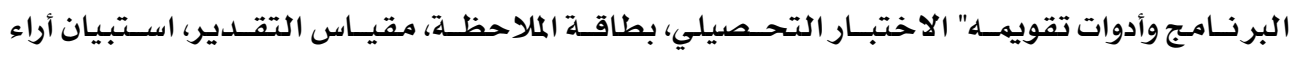

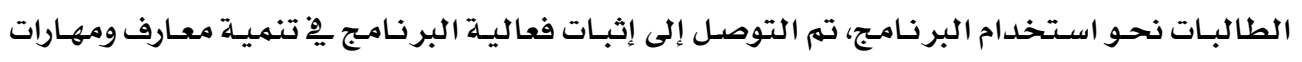

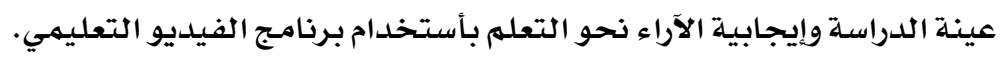

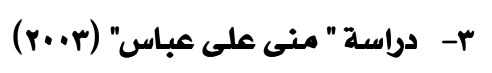

\section{بعنوان: فاعلية برنامج فيديو تعليمي يو تنمية بعض مهارات تنفيذ الملابس الحريمي}

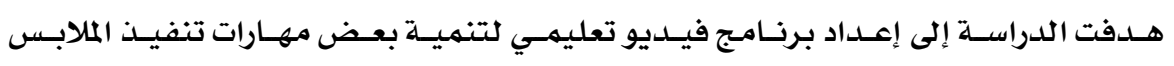

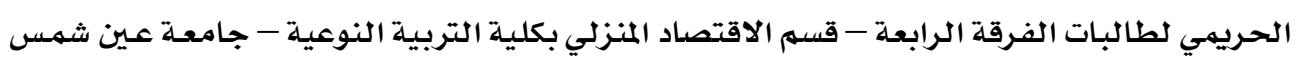

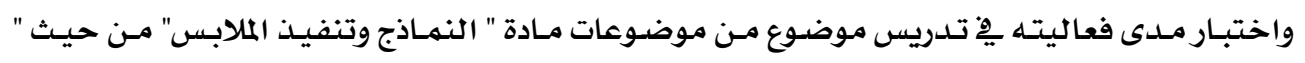

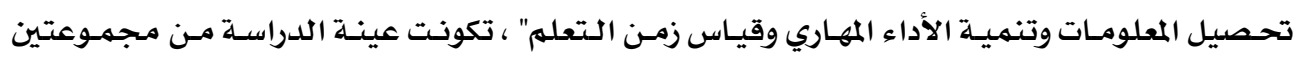

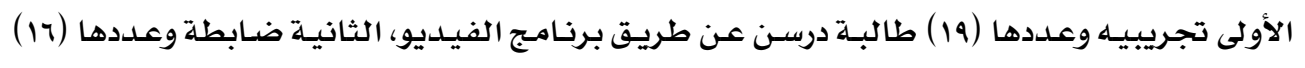

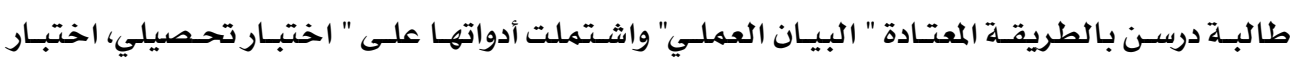

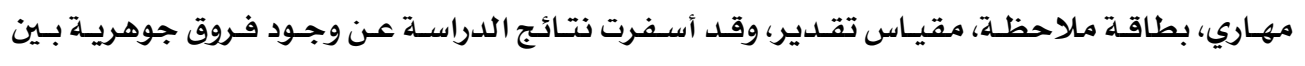

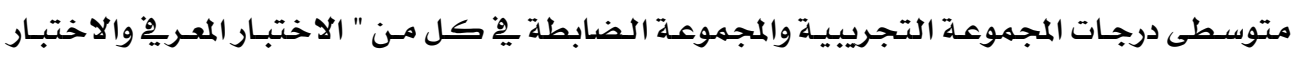

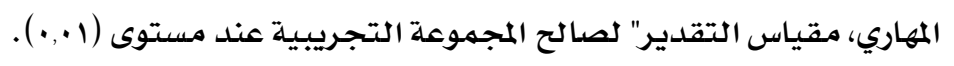




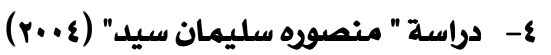

بعنوان : أثر استخدام الفيديو التعليمي ـِ تنفيذ الملابس.

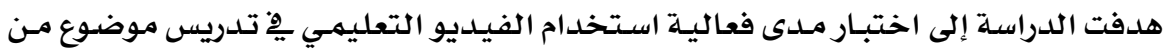

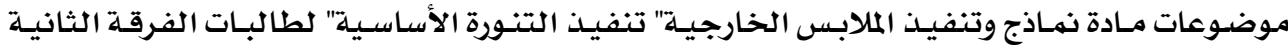

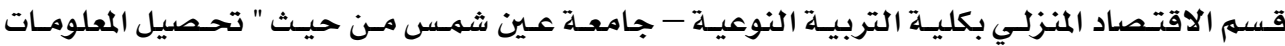

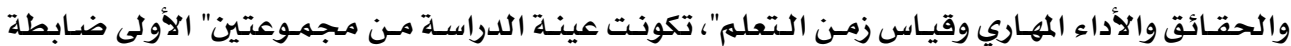

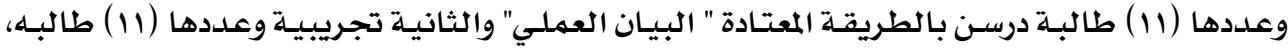

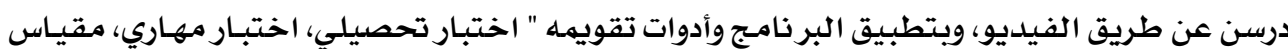

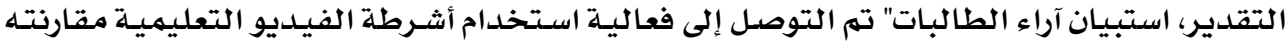

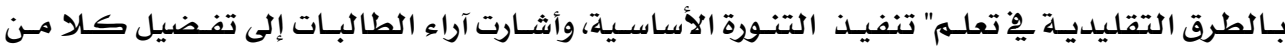
طريقتي التعلهم.

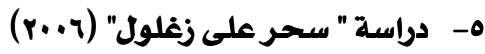
بعنوان: فعالية استخدام الفيديو التعليمي ِِّ تنمية المفاهيم والمهارات الأساسية ـِّ تصميم أزياء النساء للدى طلاب قسم الملابس والنسيج.

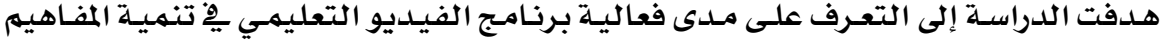
والمهارات الأسساسية يِّ تصميهم أزياء النساء لدى طلاب الفرقة الثالثة - قسم الملابس والنسيج - كلية

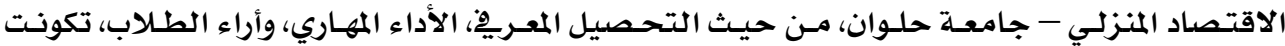

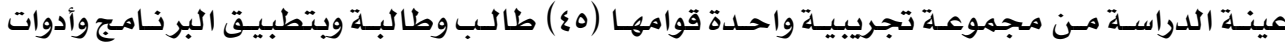

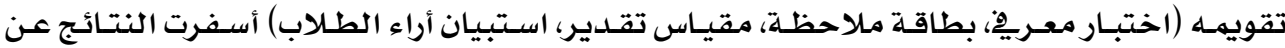

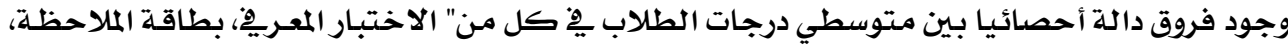
مقياس التقدير قبل وبعد تطبيق البر نامـج لصالح التطبيق البعدي، كهما جاءت آراء الطلاب إيجابيـة نحو استخدام الفيديو كطريق للتعلهم. التعليق على دراسات المحور الثاني:

ا- انحصر الهدف الرئيسي للدراسات يف استخدام الفيديو التعليمي يْ تنميـة معـارف ومهارات

$$
\text { الطلاب فِّْ مجال الملابس والنسيـج. }
$$

ץ- تنوعت أدوات الدراسـة من " إختبـارات معرفيـة، اختبـارات مهاريـة، بطاقـات ملاحظلة استبيانات

$$
\text { أراء الطلاب. }
$$

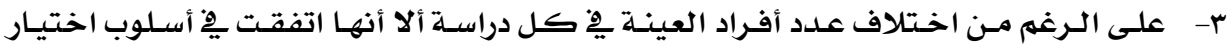

العينة" الأسلوب العشوائي" الذي يتلائم مع طبيعة تحقيق أهداف الدراسـة التجريبية.

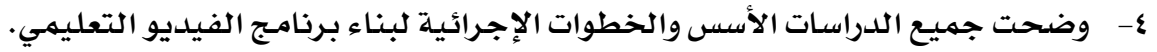

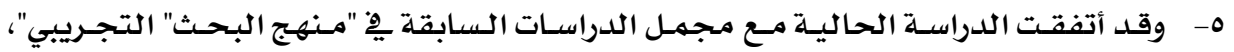

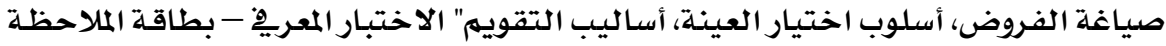




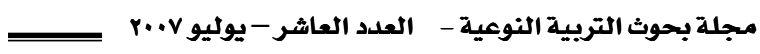

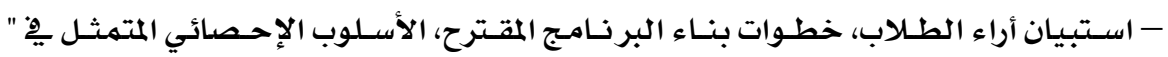

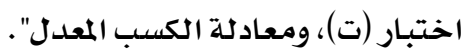

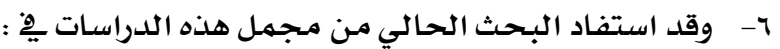

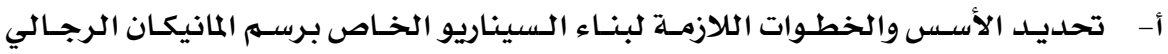
التعليمي المواجه بأوضلاع حركية مختلفية.

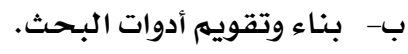
ج- تفسير نتائج الدراسلة.

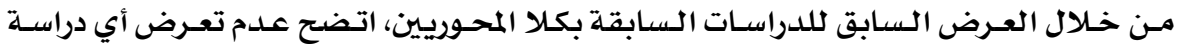

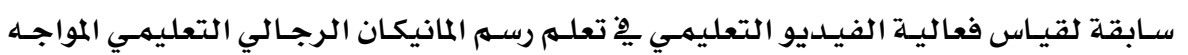

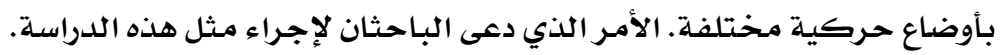
فروض البحث:

ا- توجد فروق دالة إحصائياً بين متوسطى درجات الطلاب يِّا الأختبار المعربِّ قبل وبعد تطبيق البرنامهج لصالح التطبيق البعدي.

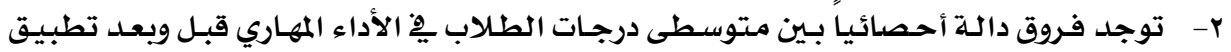
البرنامهج لصالح التطبيق البعدي. r- برنامج الفيديو التعليهي يساعد على تكوين آراء إيجابية نحو طريقة التعلم لدى الطلاب. المفاهيم النظرية:

$$
\text { طبيعة البناء الهيكلي والعضلي لجسهم الرجل: }
$$

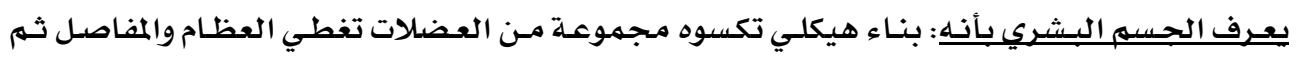

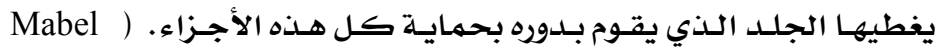

(Erwan,1997,54

$$
\text { وفيما يلي توضيح لطبيعة البناء الهيكلي والعضلي لجسم الرجل }
$$

أولاً: البناء الهيكلي : شكل رقم (1)

تكون العظام هيكل بناء الجسهم ويتكون الهيكل العظمي من الهيكل المحوري والهيكل الطريِّ.

$$
\text { أ أهيكل المحوري: يتكون من }
$$

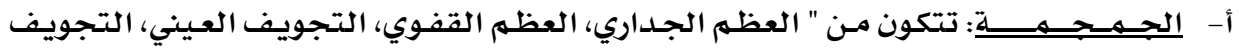

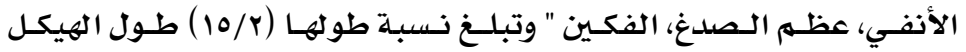

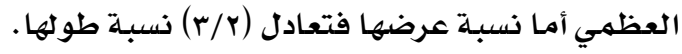

ب- العمـود الفقـري: يمتــ مـن أسـفل الجمجمـة حتى نهايـة الجـذع، ويتكـون مـن ثلاثة وثلاثون

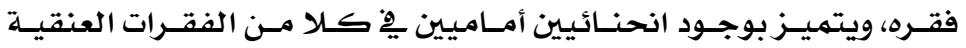


والقطنيه وانحنائين خلفيين ِِْ كالا من الفقرات الصدرية والجزعية وتبلغ

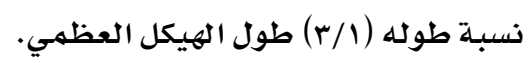

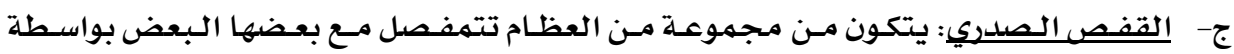

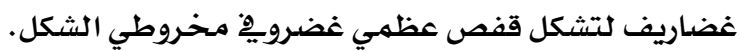

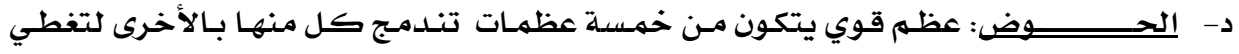

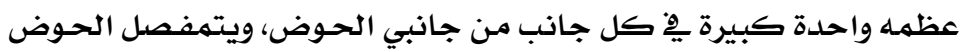

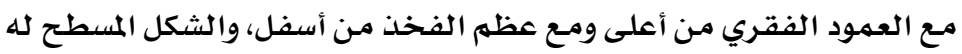
يشبـه شبه المنحرف.

$$
\begin{aligned}
& \text { r- الهيكل الطريف: يتكون من عظام الطرف العلوي، وعظام الطرف السفلي } \\
& \text { أ - عظام الطرف العلوي: تتكون من }
\end{aligned}
$$

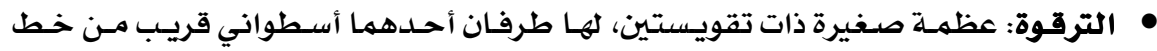

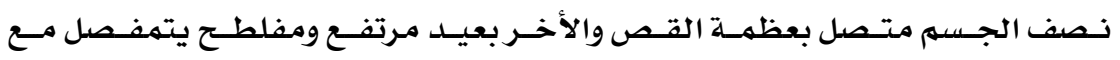

$$
\text { عظمة اللوح. }
$$

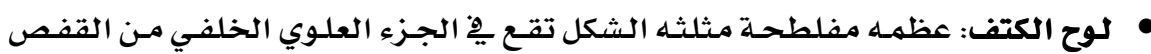

$$
\text { الصدري، يتمفصل مـع عظمتي القطن والترقوة. }
$$

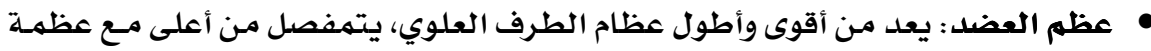

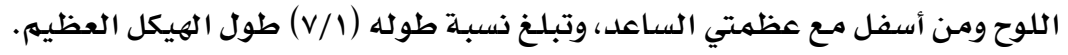

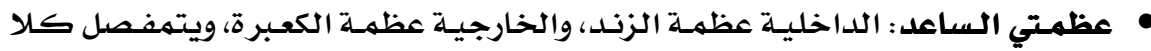

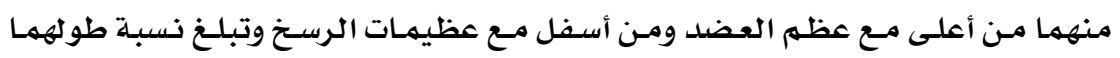

$$
\text { طول عظم العضد. }
$$

• عظام اليد : تتكون مـن ثلاثة أجزاء "عظيمات الرسخ، الأمشاط، السـلاميات".

$$
\text { ب- عظام الطرف السفلي: تتكون من }
$$

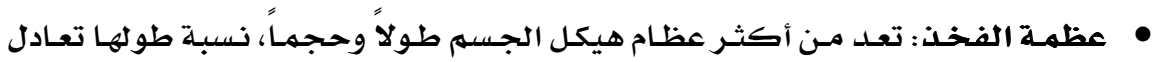

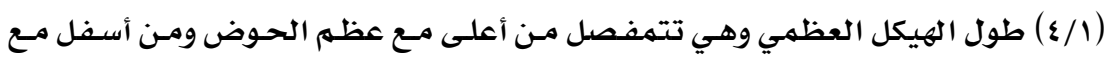

$$
\text { عظمـة القصبـة. }
$$

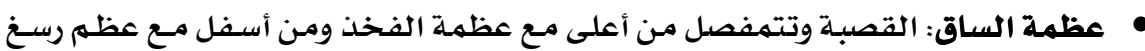

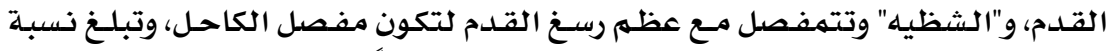

$$
\text { طول كلا منهما (V/r) طول عظام الطرف السفلي تقريبا. }
$$

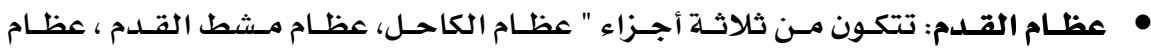

$$
\text { أصسابع القدم. }
$$




$$
\text { ثانياً: البناء العضلي لجسم الرجل: شكل رقم (ץ أبب) }
$$

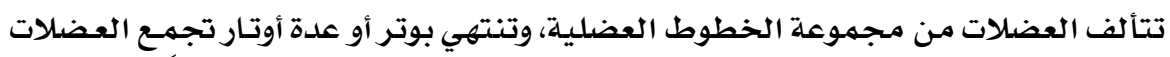

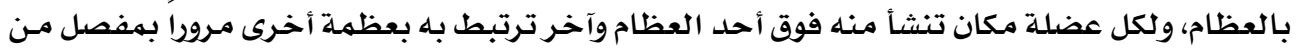

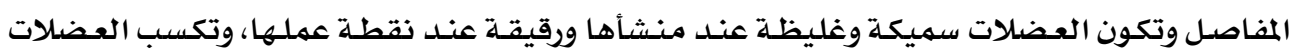
المفاصل الشكل الكروي المتميز لها. وفيما يلي توضيح لبعض عضلات الجسم التي تتحكم ِِّ بناء هيئته الخارجية. 1- عضلات العنق: تشمل " العضلة المربعة المنحرفة، ناحية العهمود الفقري، الرئيسية البـارزة

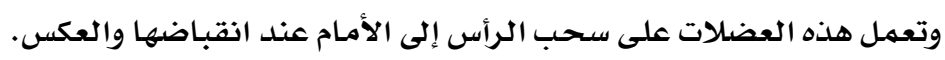

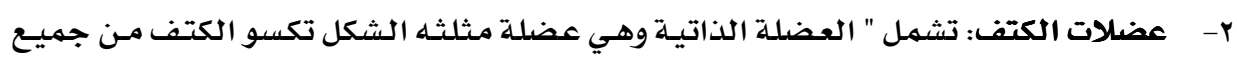
الجوانب، العضلة فوق الشوكيه وهي عضلة تملئ الحفرة الموجـودة فوق شـوكة عظميـه

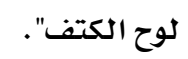

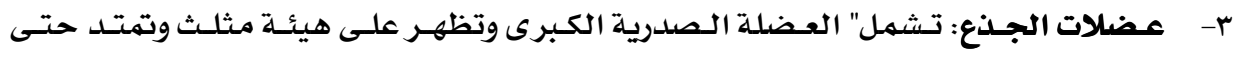

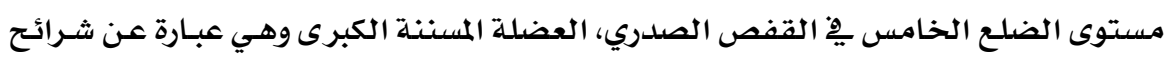

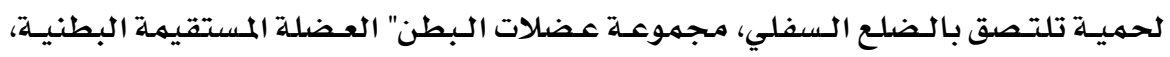

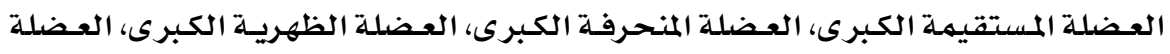

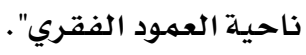

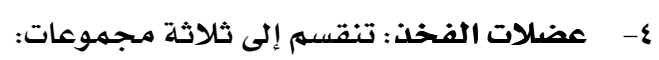

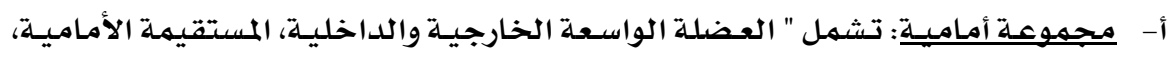

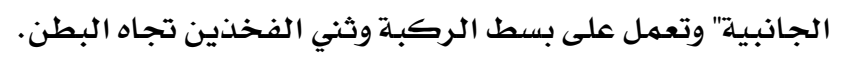

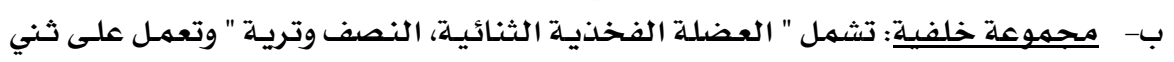

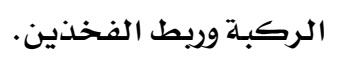

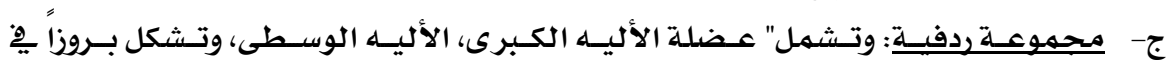
منطقة الروفين.

هـ عضلات الساق: تنقسم إلى " مجموعة أماميـة" تشمل العضلة القصبية الكبرى والعضلة

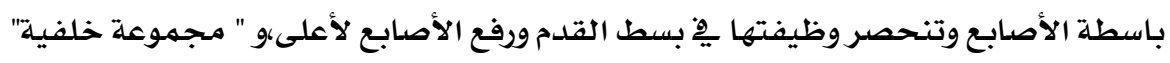

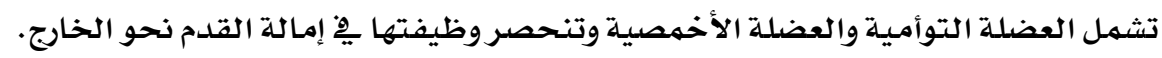

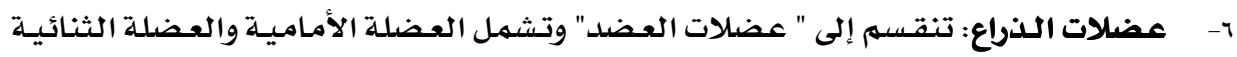

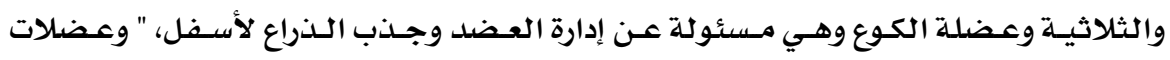

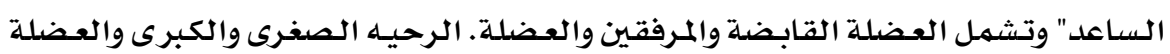


المغزلية والباسطة وتنحصر وظيفتها يِ عملية قبض وبسط اليد. (محمود محمـد قطب-

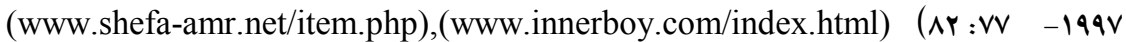
(www.mkm-haifa.co.il/schods/almotnbi/atar2003/afaf/skeleton.htm), (www.gabib.com/ask/archive/index.phppt-1389.html), (www.gabib.com/anatomy/ant-22.htm).

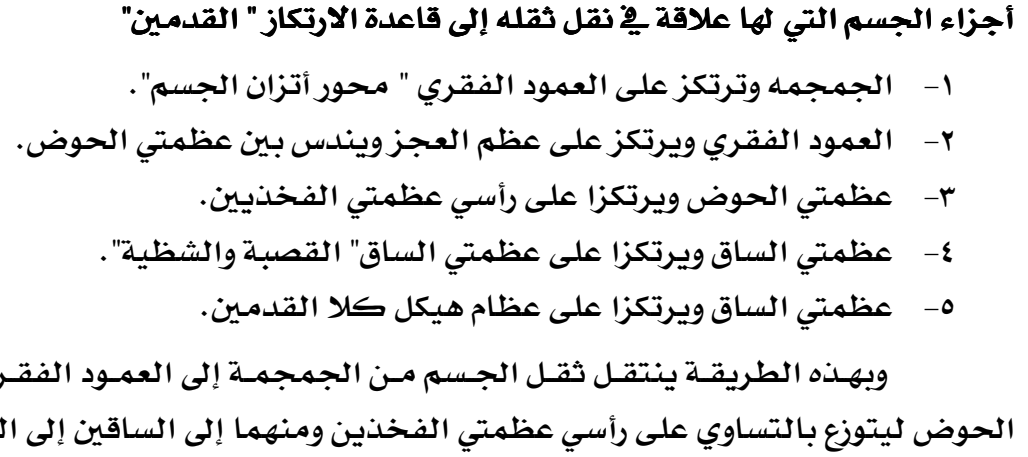

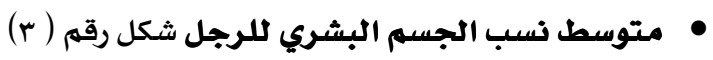

Horten )، اتفق كل مـن (Burgo Fernado: 2000: 117)، (Loomis Androw: 1980: 20)،

(James : 2000: 80 فح تحديد موضع ونسب خطوط الجسم البشري للرجل وذلك وفقا لقياس طول وحده الرأس والجدول التالي يوضـح ذلك.

جدول رقهم (1) متوسط نسب الجسه البشري للرجل

\begin{tabular}{|c|c|c|}
\hline الموضــــع & النسب وفقا لقياس & خطوط الجسهم \\
\hline----- & 1 & • • الرأس - الطول \\
\hline-----1 & $r / r$ & 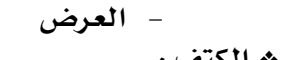 \\
\hline بلدءاً من نقطة منتصف الرقبة إلى خط قاعدة الكتفين. & $T / 0$ & - خ خط ميل الكتف \\
\hline - أسفل الرأس بمقدار (ץ/ه) طول الرأس. . & $r / r g l$ & - خط قاعدة الكتفين \\
\hline أسفل خط قاعدة الكتفين بهقدار (r/ه) طول الرأس. & 1 & 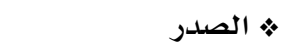 \\
\hline أسفل خط الصدر بمقدار (^/v) طول الرأس. & $r /|g|$ & • • الوسط \\
\hline أسفل خط الوسط بهقدار طول الرأس. & $r / \mid$ & 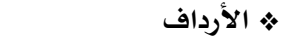 \\
\hline أسفل خط الأرداف بهقدار (اوه/^) طول الرأس. & $0 / r$ & 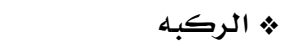 \\
\hline أسفل خط الركبة بهقدار ( ( / طول الرأس. & $r / 1$ & 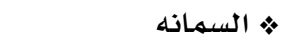 \\
\hline أسفل خط السمانة بهقدار (او / / ) طول الرأس. & $\varepsilon / 1$ & 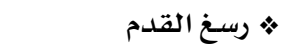 \\
\hline أسفل خط رسـخ القدم بهقدار (r/^) طول الرأس. & $0 / r$ & • أطراف القدم \\
\hline أسفل نقطة نهاية الكتف بهقدار (اوا /ه) طول الرأس. & $r / 1$ & 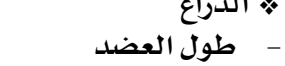 \\
\hline أسفل نقطة نهاية العضد بهقدار (اوا/ه) طول الرأس. & $r / 1$ & 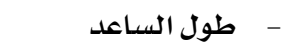 \\
\hline أسفل نقطة نهاية السـاعد بمقدار (//ه) طول الرأس. & $0 / r$ & طول اليد \\
\hline
\end{tabular}




$$
\text { • متوسط نسب المانيكان الرجالي التعليمي }
$$

تعرف (كفاية سليمان، نجوى شكري، 1999، v) المانيكان بأنه رسـم تخطيطي الجسهم بشري، يرسهم بنسب أكثر مبالغة عن نسب رسهم الجسهم، يستعين به مصمموا الأزياء يِ توضيح أفكارهم التصميمية

$$
\text { عن طريق رسهم الاسكتشات عليه. }
$$

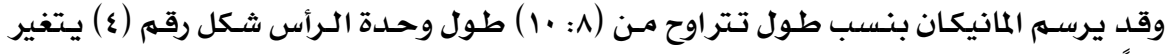

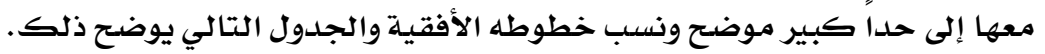

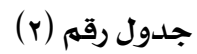

\begin{tabular}{|c|c|c|c|c|c|}
\hline عشرة وحدات & تسعة وحدات ونصف & تسعة وحدات & ثمانية وحدات ونصف & ثمانية وحدات & 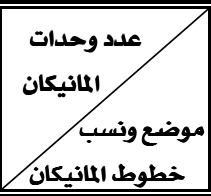 \\
\hline & & & & 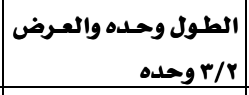 & طول الرأس وعرضها \\
\hline & 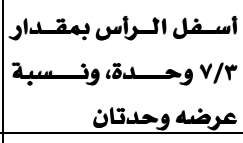 & 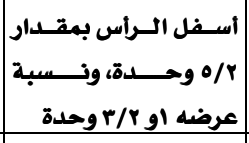 & 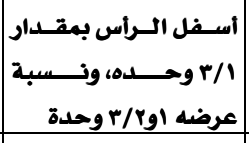 & 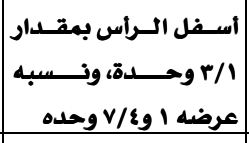 & خط قاعدة الكتفين \\
\hline | أسفل الرأس بمقدار ا و وحدة & 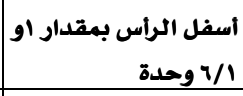 & | أسفل الرأس بمقدار 1 وحده | & & |وحدة أسـفل الـرأس بمقـدار & خط الصلدر \\
\hline 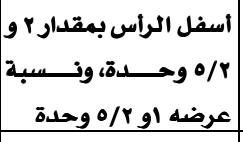 & أ أسفل الرأس بمقدار rوحة & 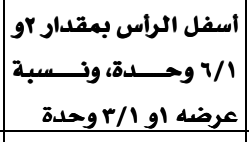 & 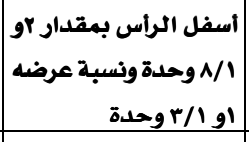 & 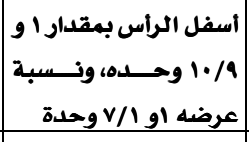 & خط الوسط \\
\hline 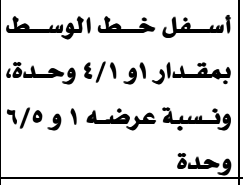 & 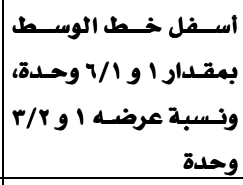 & 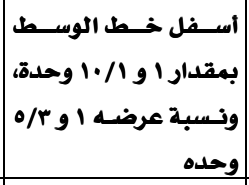 & 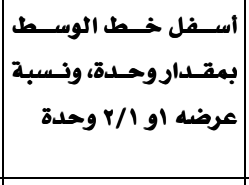 & 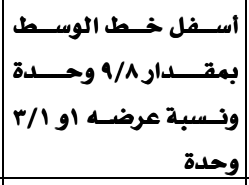 & خط الأرداف \\
\hline 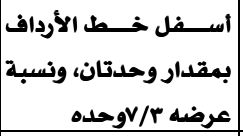 & 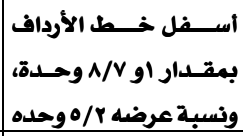 & 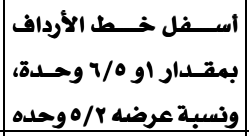 & 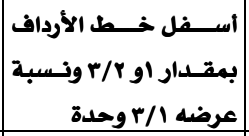 & 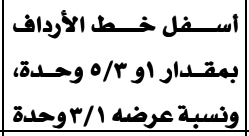 & خط الركبة \\
\hline 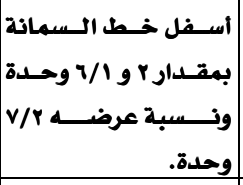 & 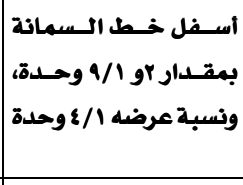 & 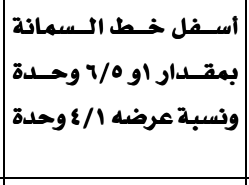 & 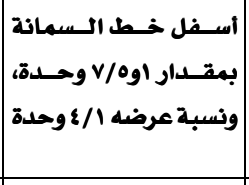 & 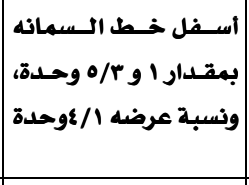 & خط رسيخ القدم \\
\hline & & 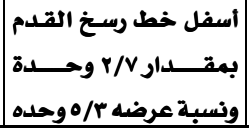 & 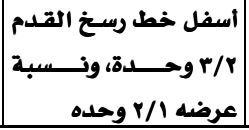 & 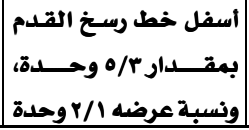 & خط أطراف أصابع \\
\hline
\end{tabular}

متوسط موضع ونسب خطوط المانيكان المرسوم بطول وحدات رأس تتراوح من (^: • 1) وحدات 
النقاط الواجب مـراعاتها عند رسم المانيكان:

ا- تحلديد موضع خط الارتكاز " الاتزان"

ويهتد هذا الخط رأسياً من نقطة منتصف الرقبة إلى خط قاعدة ارتكاز القدمـين، فعند رسهم

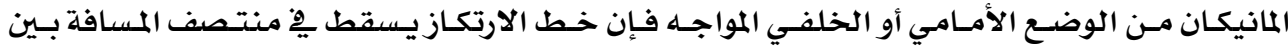

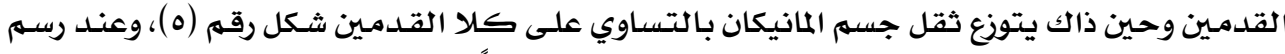

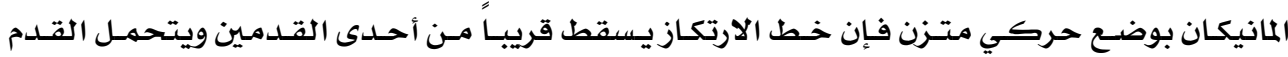

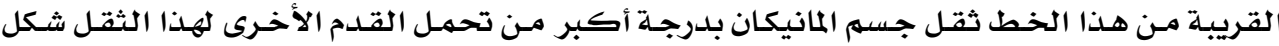

رقم (7).

\section{r- ت تحديد موضع خط نصف المانيكان}

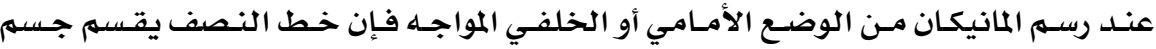

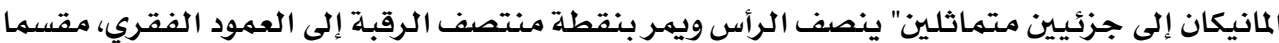
منطقة الحوض ثم تسقط ِِِ منتصف المسافة بين القدمين شكل رقم (v) .

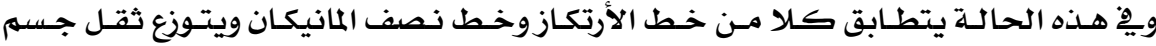
المانيكان بالتسـاوي على القدمـين.

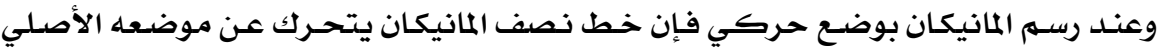

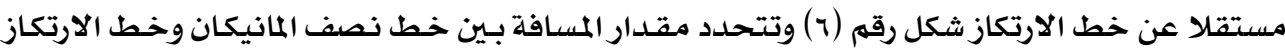
وفقا لطبيعته الوضع الحركي المراد رسمـه فكلما زادت المسافة بين كالا الخطين زادت زاوية ميل كل كل

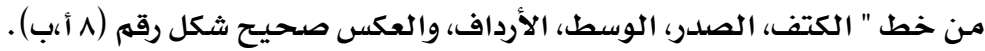
r- تحديد زاوية ميل كل من خط" الكتف، الصدر، الوسط، الأرداف" وعن رسهم المانيكان من الوضع المواجه ترسهم خطوط" الكتف، الصدر، الوسط، الأرداف" موازية

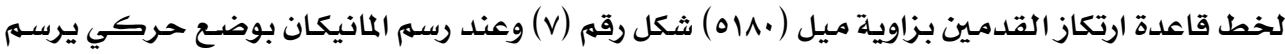
خطي الكتف والصدر" موازيان بشكل عكسي لخطي الوسط والأرداف. وتتوقف درجة زاوية ميل كل خط على مقدار بعد المسافة بـين خطي نصف وارتكاز المانيكان كما سبق شكل رقم (^ أ، ب). ويجلدر الإثـارة إلى أن القدم التي يتم تحميل ثقل جسهم المانيكان عليها بـدرجة كبيرة تقع مِِ الجانب الذي يرتفع فيه خط الأرداف عن موضعه الطبيعي. إجراءات البـحث:

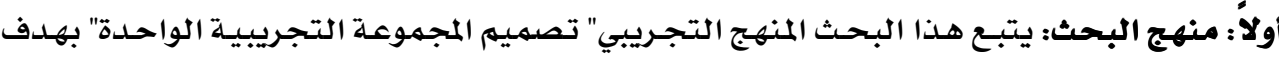
التعـرف على تـأثير المتغير المستقل " برنـامج الفيـليو التعليهـي على المتغير التـابع" المفـاهيه

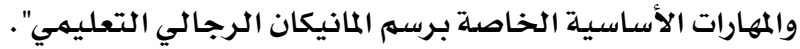


تكونت عينـة البحـث الاستطلاعية مـن عـد ( • (1) طلاب مـن الفرقـة الثانيـة - شعبـة الملابس

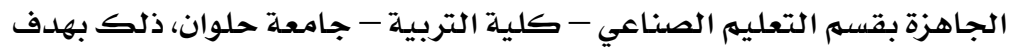

• التحقق من البيانات السيكومترية للاختبـار المعـريخ، وبطاقـة ملاحظلة الأداء المهاري، استبيان آراء الطلاب.

• التأكد من دقة وسهولة فهم التعليمات المقدمـة ِِّ البرنامـج وإمكانية تنفيذها.

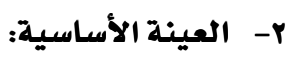

اشتملت عينـة البحـث الأسـاسـية على عدد ( •r) طالب / طالبـة مـن الفرقـة الثانيـة - شعبـة

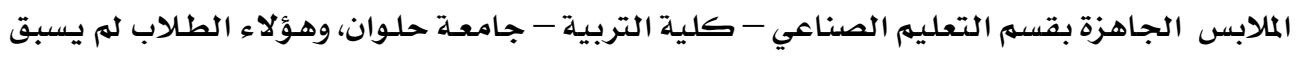

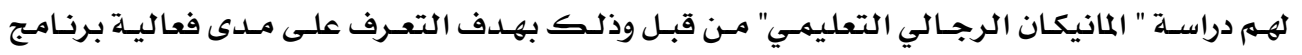

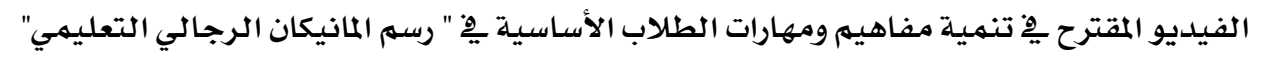
ثالثاً : أدوات البحث: اشتملت أدوات البحث علي:

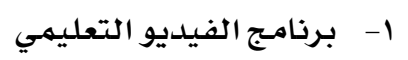

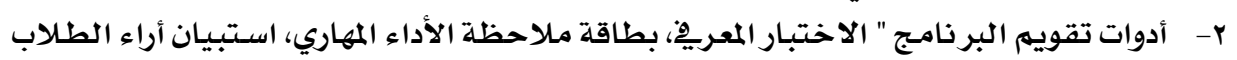

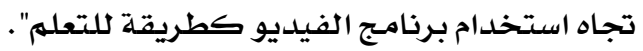
- خطوات الإجرائية خأعداد برنامـج الفيديو التعليمي

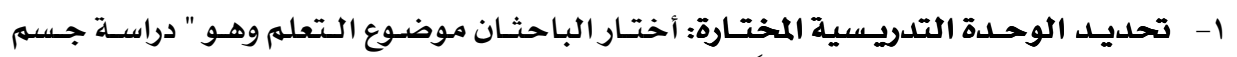

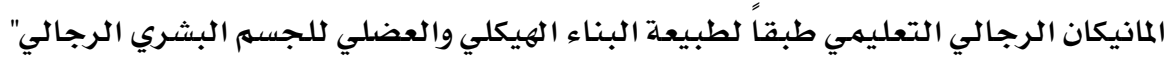

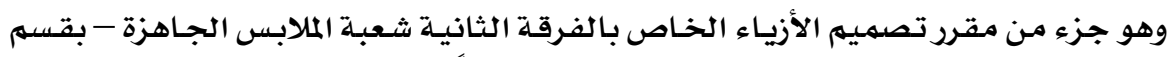

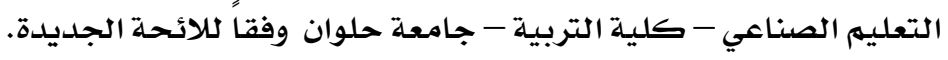

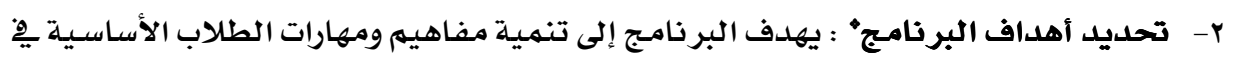

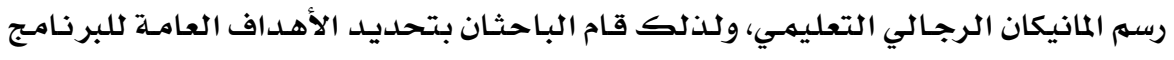

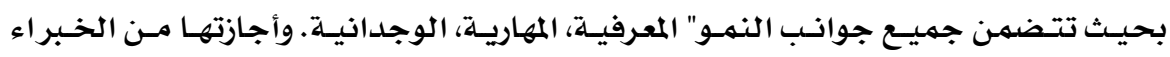
المتخخصصين.

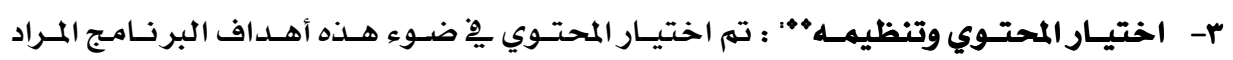

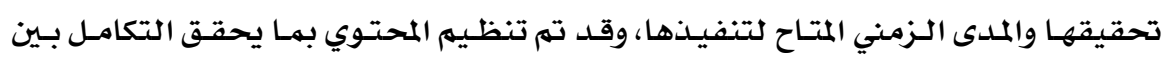
الإطاريين المعرفة والمهاري. 


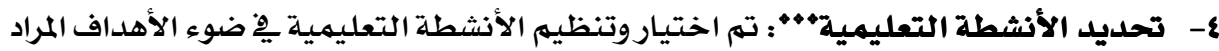

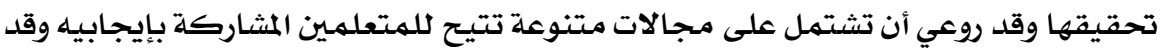
تضمن البرنامج الأنشطة الآتية.

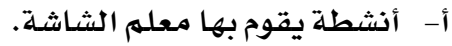
ب- أنشطة يقوم بها معلم الفصل.

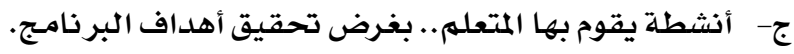

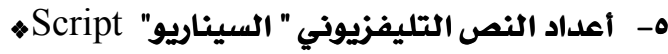

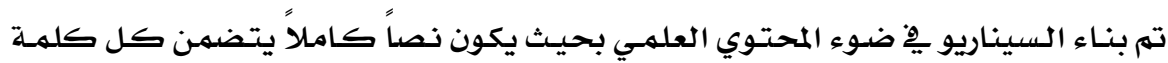

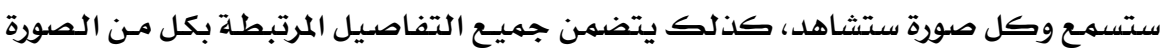
والصوت، وأجازته من الخبر اء المتخصصين.

؟- تنفيـــ الـنص التلفزيـوني " تــوير شـريط الفيـديو.. وإجـراء عمليـة التوليـف" المونتـاج"،

$$
\text { والدبلجة الصوتية. }
$$

V- تقويم برنامـج الفيديو: بعد أعداد البـاحثان" لبر نامـج الفيديو" ومـراجعته للتأكد مـ خلـوه

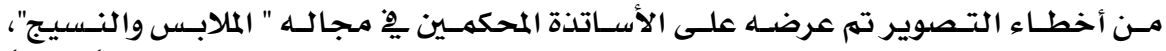

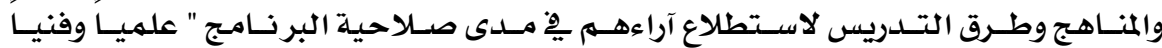

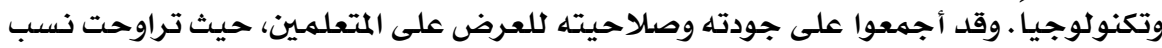

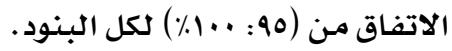
ه خطوات أعداد أدوات تقويم البرنامـج

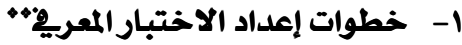

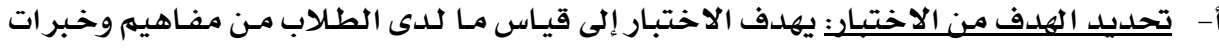

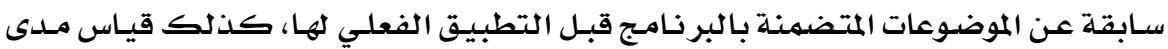
تحصيل الطلاب للمعارف المتضمنـة بالبر نامـاج. بـــــيـاغة أسئلة الاختبـار: روعي عند صياغة أسئلة الاختبار ما يلي: • ألا تتضمن من الألفاظ ما قد يوحى للطالب بالإجابة. • ألا تكون إجابة أي سؤال متضمنـة هِ أسئلة أخرى.

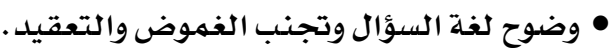
• ارتباطها بالأهداف المراد تحقيقها. 


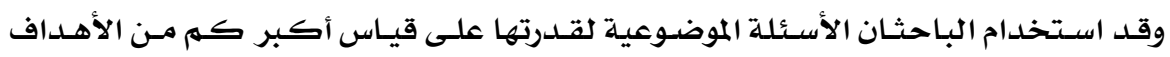

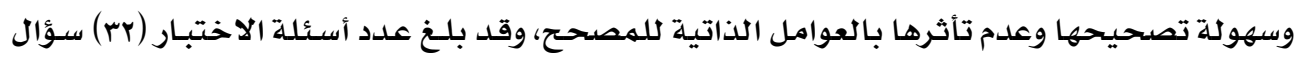

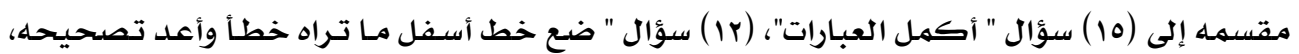

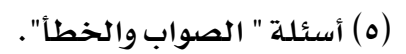

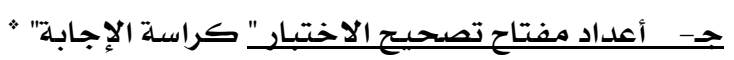

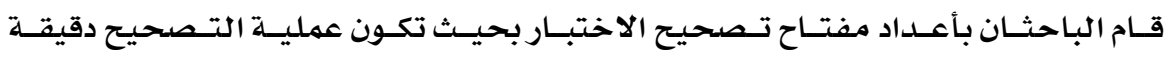

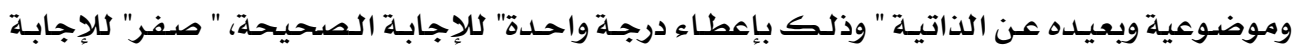

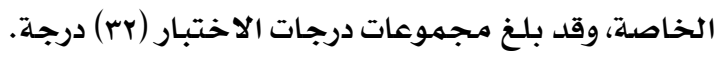

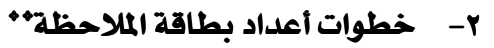
أ- ـ تحديد الهدف من بطاقة الملاحظة: قام البـاحثان ببنـاء بطاقـة ملاحظة مستوى أداء الطلاب

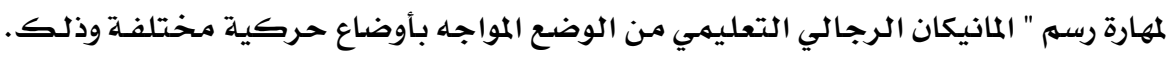

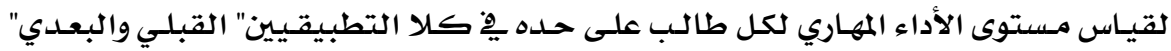
لمعرفة مدىى قدرة البرنامج على تنمية مهارات المتعلمـين.

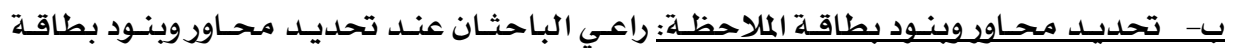

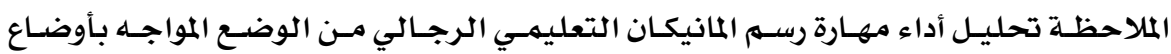

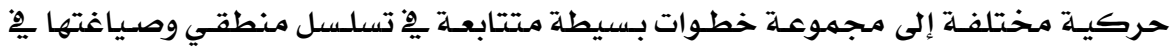

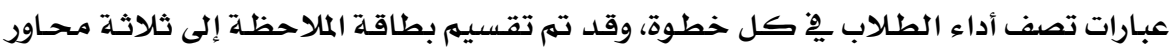

$$
\text { رئيسية كالتالي: }
$$

المحسـور الأول: يتضمن " رسهم المانيكان الرجالي التعليهمي من الوضـع المواجه".

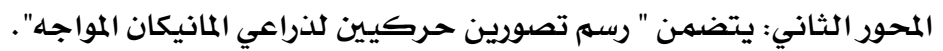

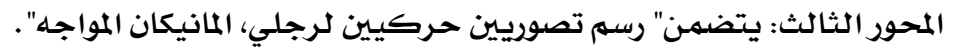

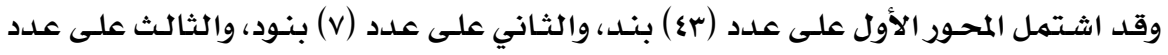

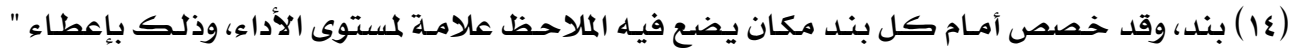

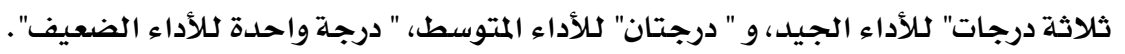

جـ- خطوات أعداد استبـيـان آراء الطلاب"

أ) تحديسد الهـدف مـن الاسـتبيان: يهـدف الاسـتبيان إلى التعـرف علـى أراء الطـلاب تجــاه

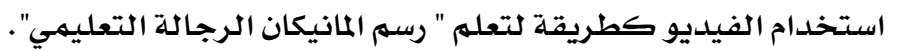

ب) تحديد محاور وبنود الاستبيان: تم بقسم الاستبيان إلى أربعة محاور كالتالي:

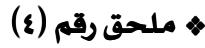

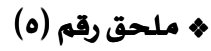

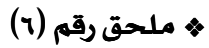




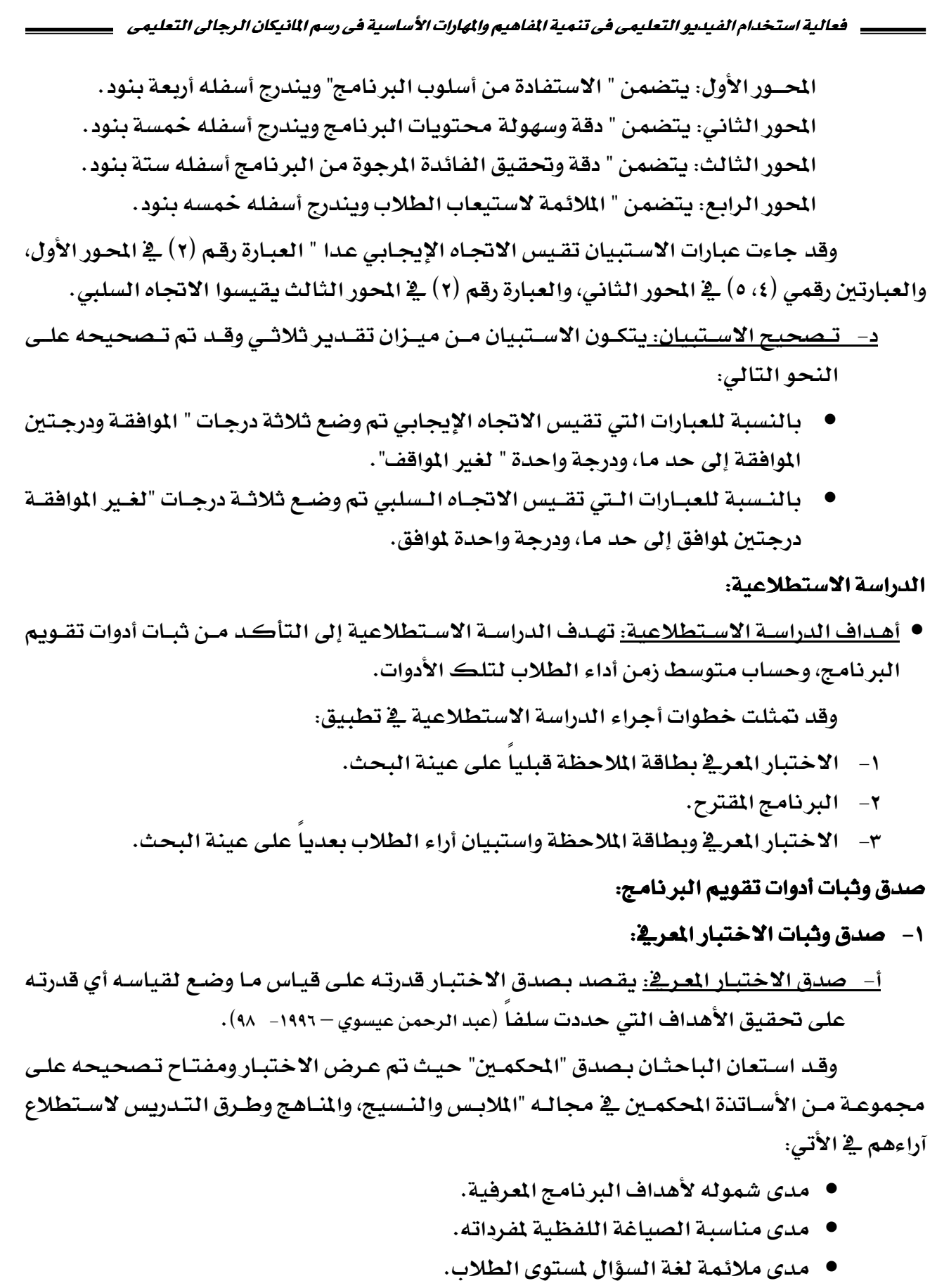




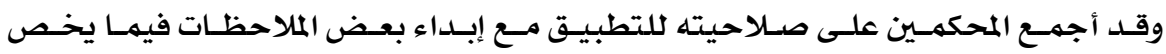

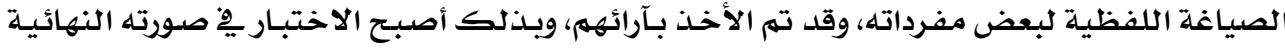
صالح للتطبيق.

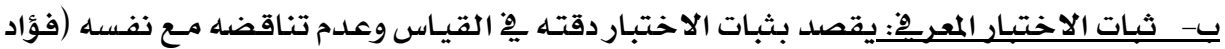

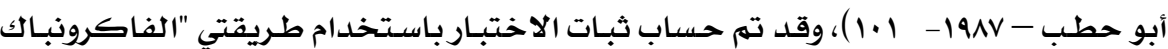
Cron bach's Alpha

بالبرنامج الإحصائي (Spss).

Statistic packages for social الحسـزم الإحسـصائية للعلـوم الاجتهماعيسة

"science

جدول رقم (r)

معامل ثبات ألفا ومعامل التجزئة النصفية للاختبار المعربِ

\begin{tabular}{|c|c|c|c|c|}
\hline \multicolumn{2}{|c|}{ معامل التجزئة النصفية } & \multirow{2}{*}{ معامل ثبات } & \multirow[b]{2}{*}{ الاختبار } & \multirow[b]{2}{*}{ r } \\
\hline بعد التصديح مـن الثر التجزئة & قبل التصديح من التجزئة & & & \\
\hline$\cdot 9$ & $\cdot$ •, & $\cdot 9 r$ & 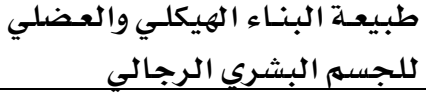 & 1 \\
\hline$\cdot, \wedge \Lambda$ & $\cdot, \mathrm{V} \wedge$ & $\cdot, \wedge \mathrm{V}$ & رسهم المانيكان الرجـالي التعليهي & r \\
\hline$\cdot, 9 \cdot$ & 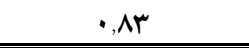 & $\cdot, \wedge 9$ & الدرجـة الكليـة للاختبـار & $r$ \\
\hline
\end{tabular}

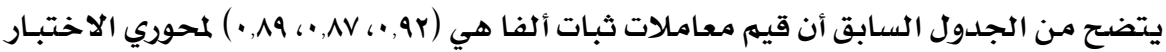

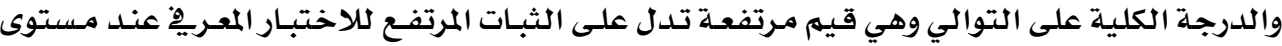

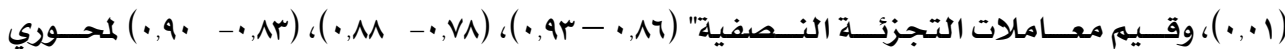
الاختباروالدرجة الكلية على التوالي، حيث أن القيمة الأولى لكل جزء تـدل على ثبـات نصف الاختبـار

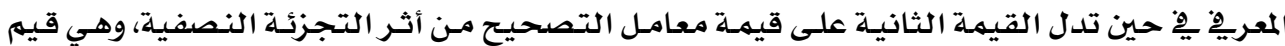

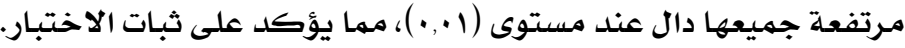

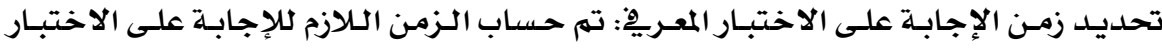

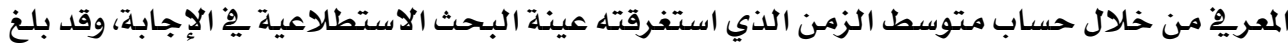
متوسط زمن الإجابة (0ـ ) دقيقة.

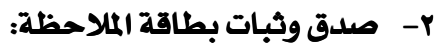
أ- صدق بطاقة الملاحظة:

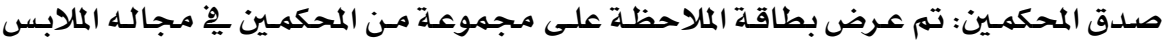

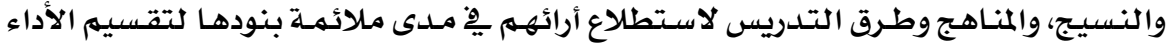


المهاري، وقـد أجمـع المحكمـين على صـلاحيتها للتطبيق، وقد كانت هنـاك بعض الملاحظـات

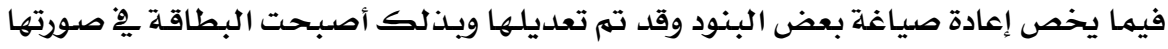

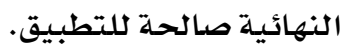

\section{بـ- ثبـات بطاقة الملاحظة:}

تم التأكد من ثبات بطاقة الملاحظة من خلال حسـاب معامل الارتباط بين درجات مصححي

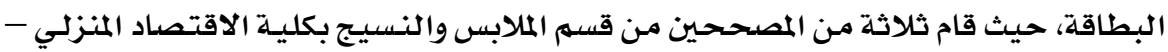

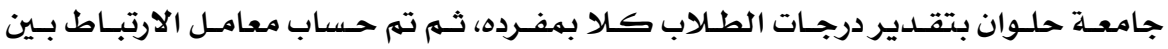
درجاتهم والجدول التالي يوضـح ذلك.

جدول رقم (๕)

قيم معاملات الارتباط بين درجات المصححين الثلاثة ِِّ بطاقة الملاحظة

\begin{tabular}{|c|c|c|c|c|}
\hline \multicolumn{4}{|c|}{ رسهم المانيكان الرجالي التعليهي } & \\
\hline مـجموع المهارات & تصوريين حركيـين المانيكان & تصوريـين حركيـين & مـن الوضـع المواجـــ & \\
\hline$\cdot, \wedge 9$ & • & $\cdot, \wedge \varepsilon$ & $\cdot, 9 \mathrm{~V}$ & س، ص \\
\hline$\cdot, \wedge \mathrm{V}$ & $\cdot, \wedge 9$ & $\cdot, 9 \cdot$ & $\cdot, \wedge 9$ & س، ع \\
\hline$\cdot 9$. & $\cdot, M$ & $\cdot, 91$ & - $9 Y$ & ص، ع \\
\hline
\end{tabular}

يتضـح من الجدول السـابق ارتفاع قيهم معامـل الارتبـاط بـين درجـات مصححسي البطاقـة حيث

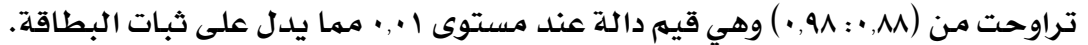

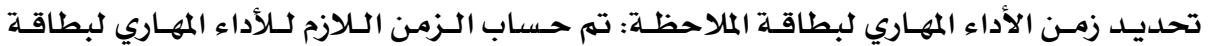

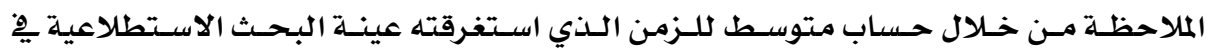

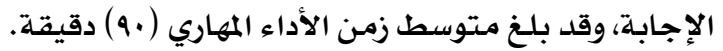
r- م- صدق وثبات الاستبيان.

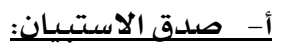

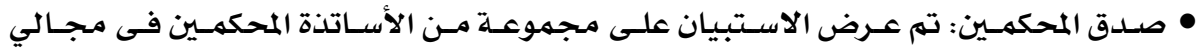

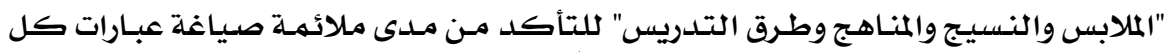

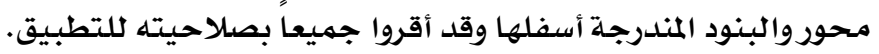
• صدق الاتساق الداخلي: قام الباحثان بحسـاب صدق الاتساق الداخلي عن طريق حساب قيهم

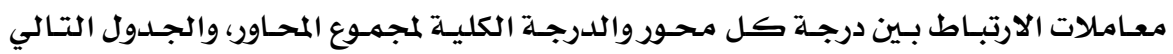
يوضـح ذلك. 


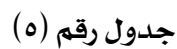

الاتساق الداخلي بين درجات محاور الاستبيان والدرجـة الكلية لمجموع المحاور

\begin{tabular}{|c|c|c|}
\hline قيمـة الارتبـاط & المحاور & $\hat{r}$ \\
\hline$\cdot, \wedge 9$ & الاستفادة مـن أسلوب البر نامـج & 1 \\
\hline$\cdot, 9$. & دقة وسهولة محتـويات البر نامـج & r \\
\hline$\%$ \% & تحقيق الفائدة المرجوة من البرنامج & $r$ \\
\hline$\% 91$ & الملائمهة لاستيعاب الطلاب & $\varepsilon$ \\
\hline
\end{tabular}

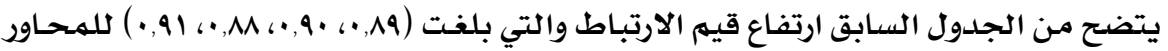

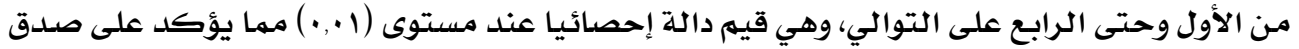

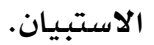

- بات الاستبيان: تم حساب ثبات الاستبيان باستخدام طريقتي" معامـل الفـا كرونبـاك "

$$
\text { والتجزئة النصفيه والجدول الآتي يوضح ذلكئ. }
$$

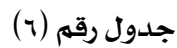

معامل ثبات ألفا ومعامل التجزئة التصفية للاستبيان

\begin{tabular}{|c|c|c|c|c|}
\hline \multicolumn{2}{|c|}{ معامل التجزئة النصفية } & \multirow{3}{*}{ معامل } & \multirow{3}{*}{ المحســـــاور } & \multirow{3}{*}{ r } \\
\hline بعد التصحيح من & قبل التصحيح من & & & \\
\hline أثر التجزئة & أثر التجزئة & & & \\
\hline$\cdot \mathrm{VA}$ & $\cdot, \wedge r$ & $\cdot \wedge 9$ & الاستفادة مـن أسلوب البرنامـج & 1 \\
\hline$\cdot, \mathrm{Vr}$ & $\cdot, \wedge \varepsilon$ & $\cdot, 9$. & دقة وسهولة محتويات البرنامـج & r \\
\hline$\cdot \mathrm{T}$ & $\cdot, \wedge \cdot$ &., 91 & تحقيق الفائدة المرجوة من البرنامـج & r \\
\hline$\cdot, \mathrm{Va}$ & $\cdot, \wedge 9$ & $\cdot, 10$ & الملائمة لاستيعاب الطلاب & $\varepsilon$ \\
\hline$\cdot \wedge 1$ & • q4 & $\cdot 94$ & الدرجة الكلية للاستبيـان & 0 \\
\hline
\end{tabular}

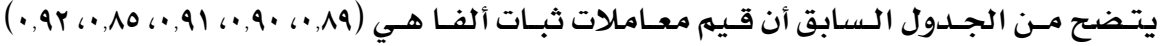

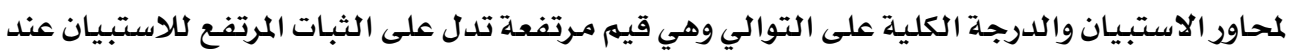

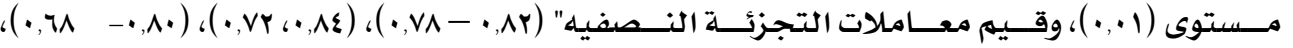

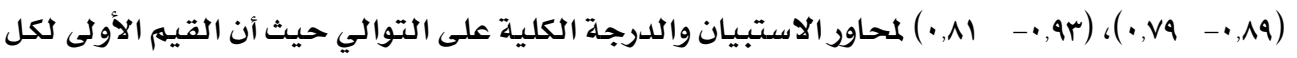

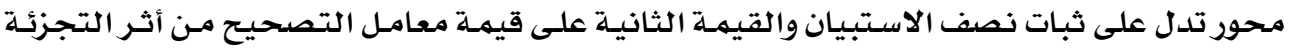
التصفية وهي قيم مرتفعة وجميعها دال عند مستوى (1, • ) مما يؤكد على ثبات ثبات الاستبيان.

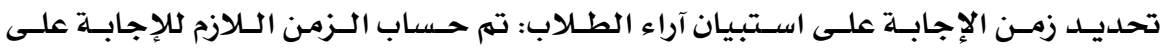

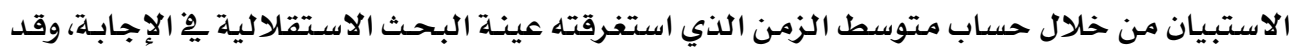
بلـغ متوسط زمن الإجابة ( •r) دقيقة. 
الدراسة الأساسية:

الهــف من الدراسـة الأسـاسيـة: تهدف الدراسـة إلى التعرف على مـدى فعاليـة برنـامج الفيديو

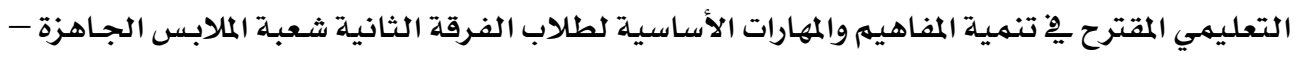

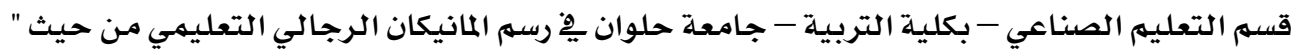

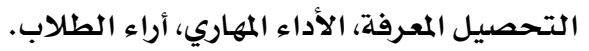

• وقد تمثلت خطوات أجراء الدراسـة يِّ تطبيق:

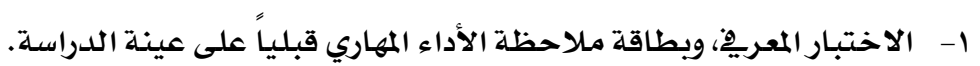

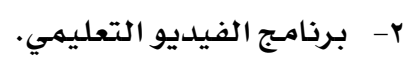

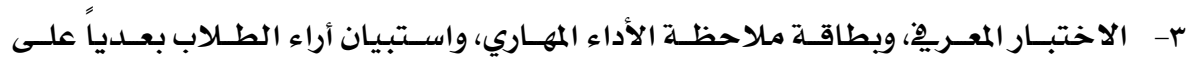
عينة الدراسـة.

تم تسسجيل النتائج ومعالجتها أحصائياً وتحليلها وتفسيرها.

$$
\text { نتائَج البحثث و تفسيرها: }
$$

الفرض الأول: ينص الغرض الأول على أنه " توجد فروق دالة احصائياً بين متوسطي درجات الطلاب مِ الاختبار المعريٍ قبل وبعد تطبيق البرنامج لكالح التطبيق البعدي.

وللتحقـق مـن صـحة هــذا الفـرض تم تطبيـق اختبــار " ت" " T.Test" لدلالــة الفـروق بـين

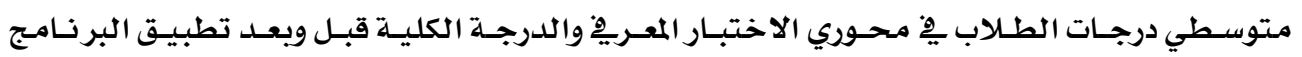
والجدول التالي يوضتح ذلك. درجات

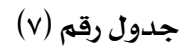

دلالة الفروق بين متوسطي درجات الطلاب ِِّ محوري الاختبار المعربِّو والدرجـة الكلية

\begin{tabular}{|c|c|c|c|c|c|c|c|}
\hline |مستوى الدلاتلة & قيمة & | درجـات & 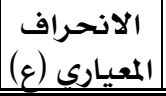 & |الحتسوسطي (م) & المقياس & محوري الاختبـار & r \\
\hline \multirow{2}{*}{ | البعدي الصالح } & \multirow{2}{*}{$\mid \wedge, r$} & \multirow{2}{*}{ rq } & $Y, q$ & $7, \varepsilon$ & قبلى & \multirow{2}{*}{ طبيعـة البناء الهيكلي والعضلي البشيري الرجالي } & \multirow{2}{*}{1} \\
\hline & & & $1, \Lambda$ & $1 V, 9$ & | ل بعدي & & \\
\hline \multirow{2}{*}{ إ·, • لصالح } & \multirow{2}{*}{$r \cdot, q$} & \multirow{2}{*}{ rq } & $1, \varepsilon$ & Y,OV & ق قبلي & \multirow{2}{*}{ رسم المانيكان الرجالي التعليهي | } & \multirow{2}{*}{ r } \\
\hline & & & $1, \cdot 1$ & $9, \mathrm{rV}$ & | بعدي" & & \\
\hline \multirow{2}{*}{ | إ·•• لصدالح } & \multirow{2}{*}{ rr,VO } & \multirow{2}{*}{ rq } & $r, v$ & $\wedge, 9 \vee$ & قبلي & \multirow{2}{*}{ الدرجـة الكلية } & \multirow{2}{*}{$r$} \\
\hline & & & $r, r$ & YV,IV & بعدى & & \\
\hline
\end{tabular}

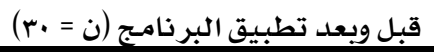

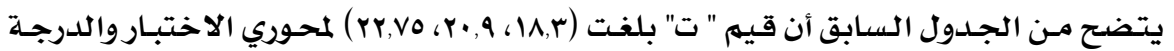

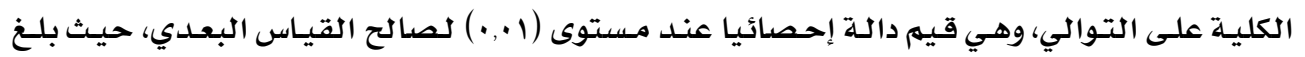

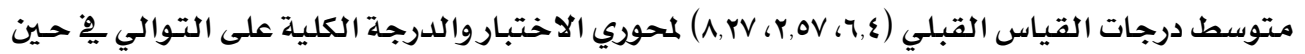

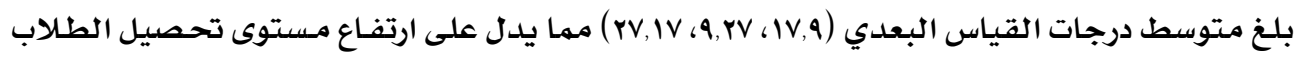


بعد دراستهم للمعارف المتضمنـة ببر نامـج الفيديو، مما يشير إلى فعاليته يِ اكتساب الطلاب للمعارف المتضمنهة بـه.

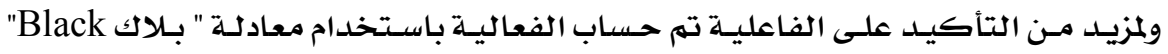

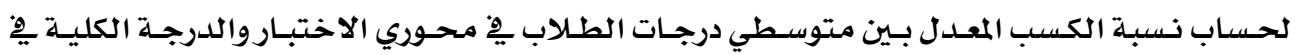

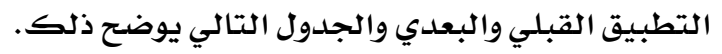

جدول رقم (^)

نسبة الكسب المعدل بين متوسطي درجات الطلاب ِِّ محوري الاختبار المعريِّ الدرجة الكلية

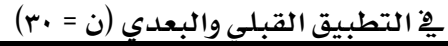

\begin{tabular}{|c|c|c|c|c|c|c|}
\hline الدلادة & نسبة الكسب & 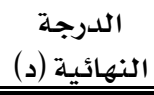 & 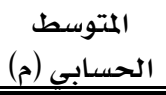 & القياس & محوري الاختبـار & r \\
\hline \multirow{6}{*}{$\frac{n}{3}$} & \multirow{2}{*}{ I,r } & \multirow{2}{*}{ rl } & $7, \varepsilon$ & قبلي & \multirow{2}{*}{ طبيعة البناء الهيكلي والعضلي البشري الرجالي. } & \multirow{2}{*}{1} \\
\hline & & & IV,9 & بعدي & & \\
\hline & \multirow{2}{*}{$1, \varepsilon$} & \multirow{2}{*}{11} & Y,OV & قبلي & \multirow{2}{*}{ رسم المانيكان الرجالي التعليمي } & \multirow{2}{*}{ r } \\
\hline & & & $9, \mathrm{YV}$ & بعدي & & \\
\hline & \multirow{2}{*}{$1, \varepsilon$} & \multirow{2}{*}{ rr } & $\wedge, 9 \vee$ & قبلي & \multirow{2}{*}{ الدرجة الكلية } & \multirow{2}{*}{$r$} \\
\hline & & & YV,IV & بعدي & & \\
\hline
\end{tabular}

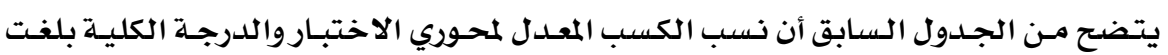

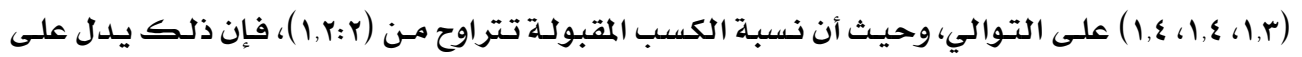

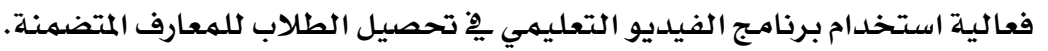

\section{• تفسير نتيجة الفرض الأول:}

أسفرت نتيجة الفرض الأول على وجود فروق دالة أحصائياً بين متوسطي درجـات الطلاب ِِّ

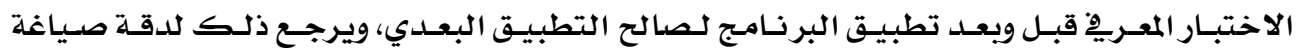

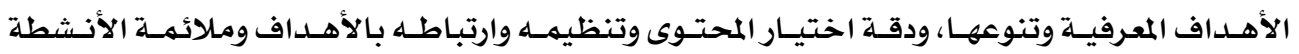
التعليمية، ودقة وموضوعية أدوات التقويهم وارتباطها بالأهداف المراد قياسها.

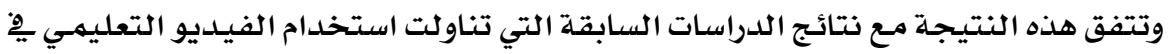

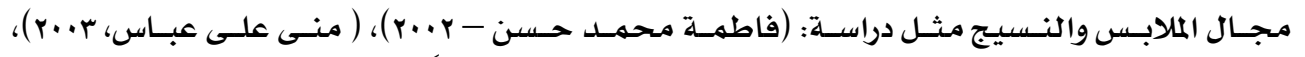

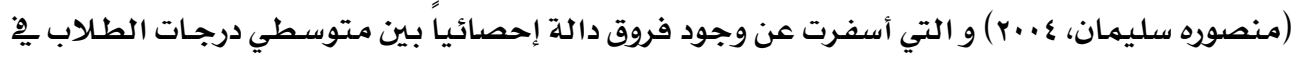

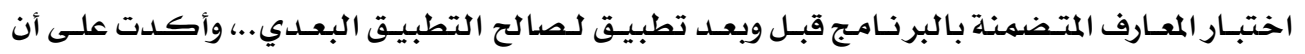
استخدام الفيديو التعليهي يسهم بشكل فعال يٍ تعلهم أكثر إيجابيهة. 
الفرض الثاني: ينص الفرض الثاني على أنه " توجد فروق دالة إحصائياً بين متوسطي درجات الطلاب

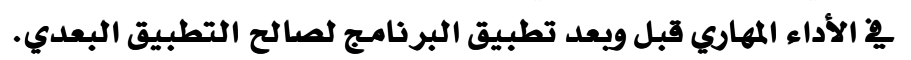

وللتحقق من صحة هذا الغرض تم استخدام معادلة "بلاك" لحسـاب نسبـة الكسب المعدل بين

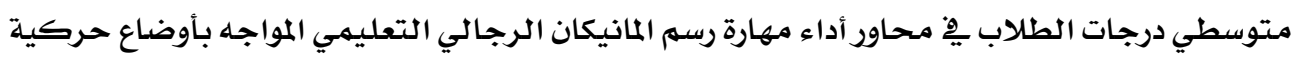

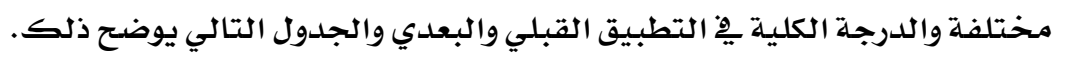

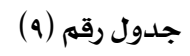

نسبة الكسب المعدل بين متوسطي درجات الطلاب ِِّ محاور أداء مهارة رسم المانيكان الرجالي التعليمي المواجه

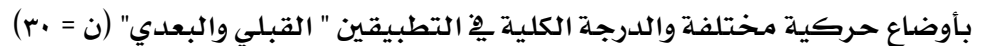

\begin{tabular}{|c|c|c|c|c|c|c|}
\hline 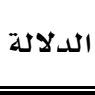 & ن المبة الكسب & 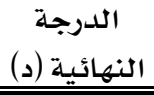 & 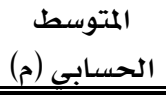 & 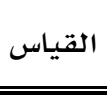 & محوري الاختبار & r \\
\hline \multirow{8}{*}{$\frac{1}{3}$} & \multirow{2}{*}{$1, V$} & \multirow{2}{*}{ lrr } & - & قبلي & \multirow{2}{*}{ رسهم المانيكان الرجالي التعليمي المواجه } & \multirow{2}{*}{1} \\
\hline & & & $1 \cdot 7, \cdot V$ & بعدي & & \\
\hline & \multirow{2}{*}{1,7} & \multirow{2}{*}{$r_{1}$} & - & قبلى ق ق ق ق ق & \multirow{2}{*}{ رسمه تصورين حركيـين لذراعي المانيكان } & \multirow{2}{*}{ r } \\
\hline & & & 17,7 & بعدي & & \\
\hline & \multirow{2}{*}{$1, \mathrm{~V}$} & \multirow{2}{*}{$\varepsilon r$} & - & قبلي & \multirow{2}{*}{ رسهم تصورين حركيين لرجلي المانيكان المواجه } & \multirow{2}{*}{ r } \\
\hline & & & $r \varepsilon, v$ & بعدي & & \\
\hline & \multirow{2}{*}{$1, V$} & \multirow{2}{*}{114} & - & 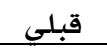 & \multirow{2}{*}{ التعليمي المواجه الكلية لرسم المانيكان الرجالي حربة مختلفة } & \multirow{2}{*}{$\varepsilon$} \\
\hline & & & lov,rV & بعدي & & \\
\hline
\end{tabular}

يتضح من الجدول السـابق أن نسب الكسب المعدل لمحاور بطاقة الملاحظة والدرجة الكلية هي الكي

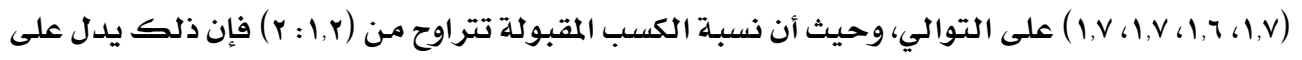

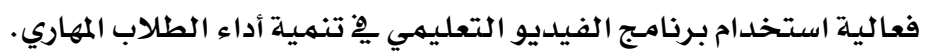

$$
\text { • تفسير نتيجة الفرض الثاني: }
$$

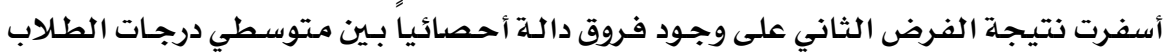

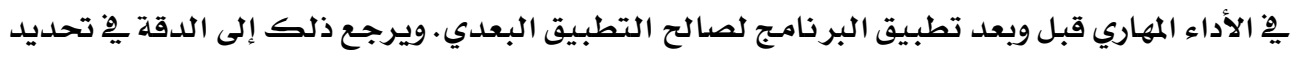

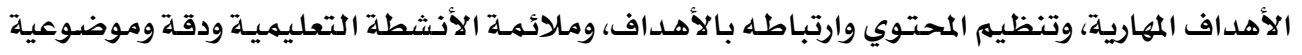

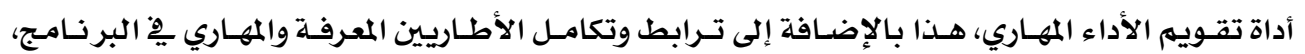

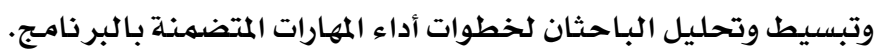

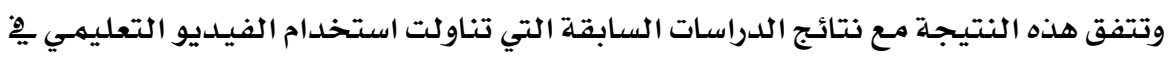

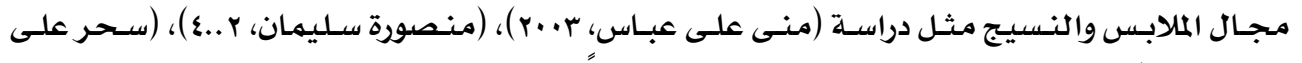

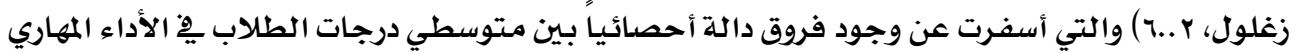

$$
\text { قبل وبعد تطبيق البرنامـج لصالح التطبيق البعدي. }
$$


الفرض الثالث: يــص الفـرض الثالث على أن " برنامـج الفيديو التعليمسي يساعد على تكوين أراء

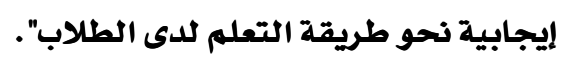

للتحقـق مـن صسحة هـذا الفـرض تم تحليـل محساور وبنـود الاستبيـان الـذي تم تطبيقـه على

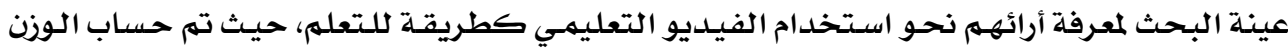

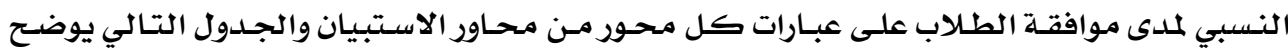
ذلك.

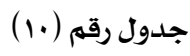

النسب المئوية لاستجابات الطلاب نحو طريقة التعلم باستخدام الفيديو التعليمي

\begin{tabular}{|c|c|}
\hline النسب المئوية & 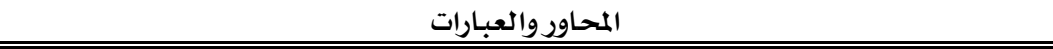 \\
\hline & المحور الأول: الاستفادة من أسلوب البرنامج \\
\hline$\% 1$. & 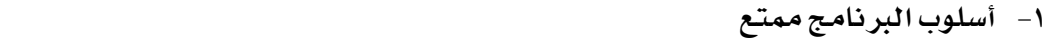 \\
\hline$\% 97$ & r - أشعر بضيق أثناء متابعتي للبرنامج \\
\hline$\%$ \% & r- لغة البرنامج واضحة ومناسبـة لي \\
\hline$\%$ \%97 & ع- أتابع بشغف شـاشـة الفيديو التعليمي \\
\hline \multirow[t]{2}{*}{$\%$ \% , r } & • متوسط النسب المئوية للمحور الأول \\
\hline & الحور الثاني: دقة وسهولة محتويات البرناميج \\
\hline$\%$ \% & 1- يحقق البر نامج " العمق والشمول والدقة ِِْ تنظيم موضوعاته \\
\hline$\%$. & r- تم تفسير المصطلحات يِ البرنامج بدقة ووضوح \\
\hline$\% 97$ & r- أشعر بهنطقية تسلسل المعارف والمهارات المتضمنـة يِ البر نامـج \\
\hline$\%$ & ع- وجدت صعوبة يِّ رسم المانيكان الرجالي التعليهي المواجه باستخدام الفيديو \\
\hline \multirow[t]{2}{*}{$\% 1 \ldots$} & 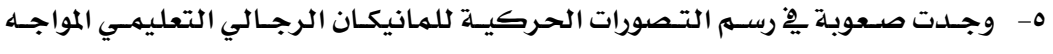 \\
\hline & باستخدام الفيديو. \\
\hline \multirow[t]{2}{*}{$\%, 90,1$} & ه متوسط النسب المئوية للمحور الثاني \\
\hline & المحور الثالث: تحقيق الفائدة المرجوة من البرنامجج \\
\hline$\%$ \%9 & 1- تزداد درجـة تحصيلي باستخدامي لبرنامـج الفيديو \\
\hline$\% 1$. & ب- البرنامـج ِِ صورته الحالية صعب الفهمم \\
\hline$\% 1$. & ب- يعد برنامج الفيديو التعليمي مـرشداً لي يِّ كل وقت \\
\hline$\%$ \%9 & ع- استفدت كثيراً من المعارف والمهارات المتضمنة بالبرنامـج \\
\hline$\% 1$. & ه- يساهم البرنامج هِ تثبيت المعارف والمهارات بذاكرتي \\
\hline$\%$ \% & 7- يحتوي البر نامج على أشكال توضيحية كافية مرتبطة بالمعارف المتضمنة به \\
\hline$\%$ \%, 0 & • متوسط النسب المئوية للمحور الثالث \\
\hline
\end{tabular}




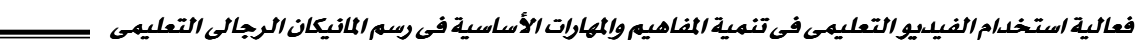

\begin{tabular}{|c|c|}
\hline النسب المئوية ائ & المحاوروالعبارات \\
\hline & المحور الرابع: الملائمة لاستيعاب الطلاب \\
\hline$\% 1 \cdots$ & 1- وجدت سهولة يخ تتبـع خطوات البرنامـج \\
\hline$\%$ & r- استطيع مـن خلال البرنامـج اكتشاف أخطائي \\
\hline$\% 97$ & r- يتوافق مستوى المحتوي مـع قدراتي يِ التفكير \\
\hline$\%$ & ع-يحسن التدريس بواسطة الفيديو التعليهي أدائي المهاري \\
\hline$\% 97$ & ه- تحسن التدريس بواسطة الفيديو التعليمي مستواي المعريخ \\
\hline$\% 90,7$ & • متوسط النسب المئوية للمحور الرابع \\
\hline$\%$ & 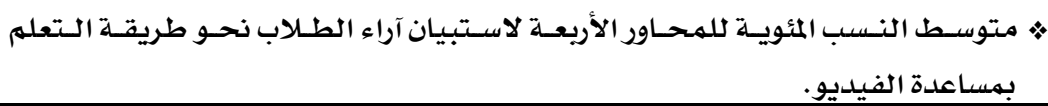 \\
\hline
\end{tabular}

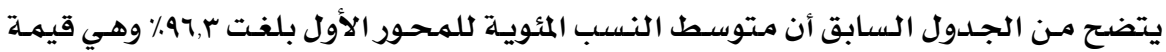

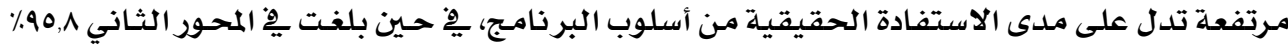

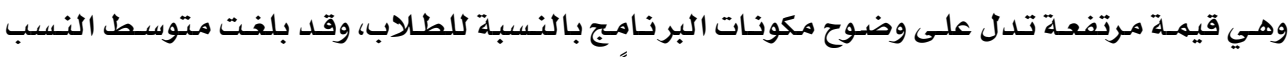

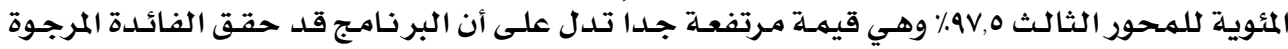

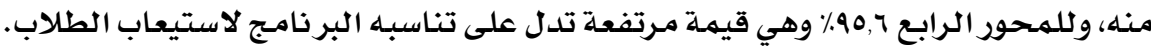

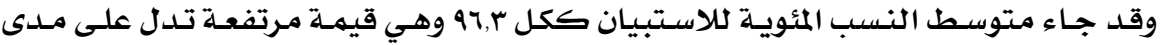
إيجابية اتجاهات الطلاب نحو التعلمه بهسـاعدة الفيديو التعليهي.

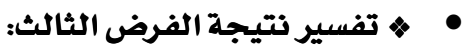

أسفرت نتيجة الفرض الثالث على أن برنامـج الفيليو التعليهي يسـاعد الطـلاب على تكوين

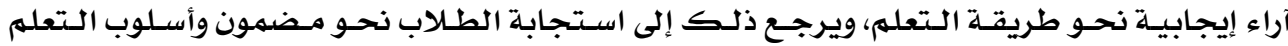

$$
\text { وتقديرهم لأهميـة مـا يـرسونه. }
$$

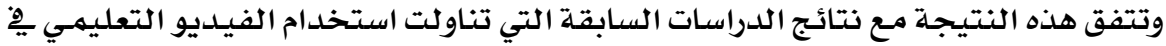

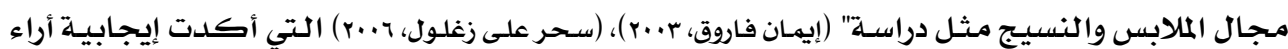
الطلاب نحو التعلمم باستخدام برنامـج الفيديو التعليهي.

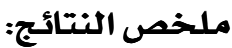

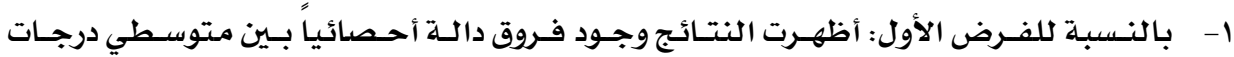

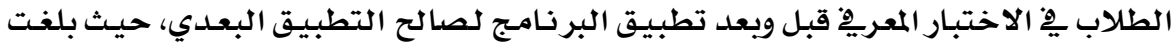

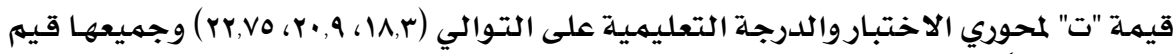

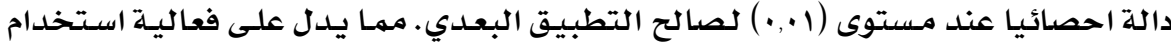
برنامـج الفيديو التعليهي يُ تحصيل الطلاب للمعارف المتضهنـة. 


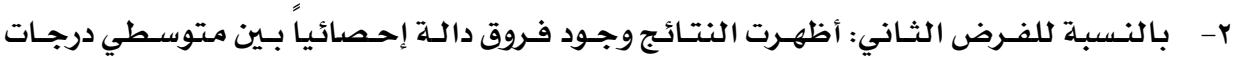

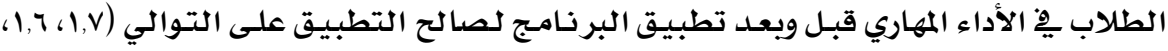

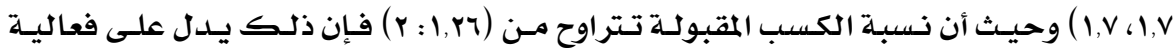

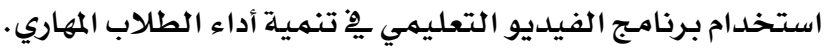

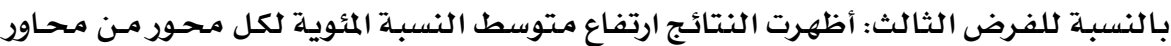

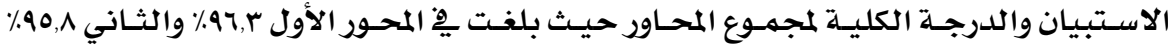

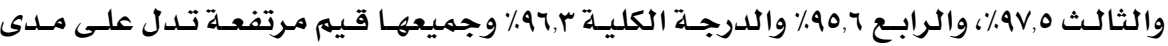

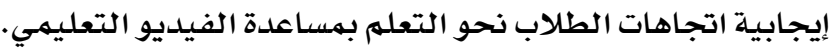

$$
\text { هِّ ضوء ما تم التوصل إليه من نتائج يوصى الباحثان بالآتي: }
$$

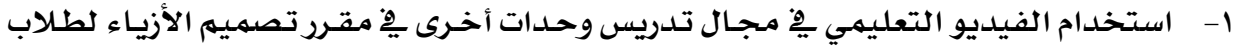

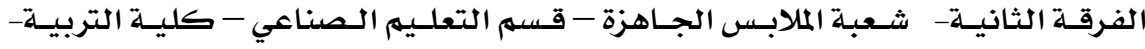
جامعة حلوان.

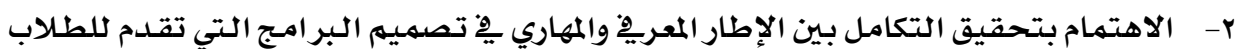
يِّ مختلف المقـررات الدراسـية بحيـث تـضيق الفجـوة بـين النظريـة والتطبيق وتـزداد كفــاءة العملية التعليمية.

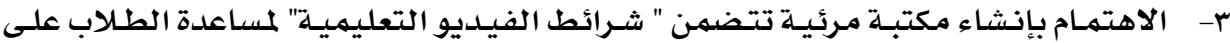

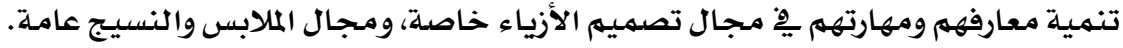




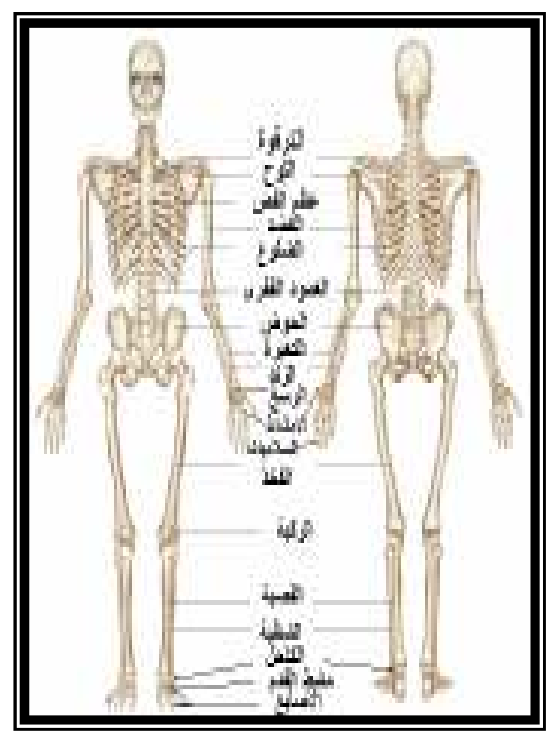

البناء الهيكلى للجسم البشرى الرجالي من الوضع الأمامي والخلفي. http://www.biology.clc.uc.edu/courses/bio 105/bone.htm

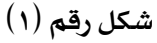

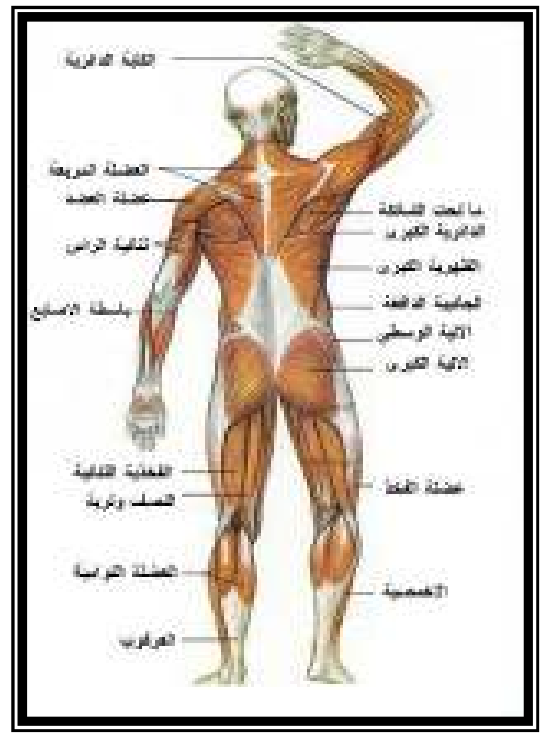

$$
\text { البناء العضلى للجسـم البشرى الرجالي }
$$

http://www.nigeriain .fonet.com/human anatomy.back.htm شكل(r)

البناء العضلي للجسم البشرى الرجالي من وضـع الأمام.

http://www.nigeriain .fonet.com/human_anatomy.front.htm شكل(r) 


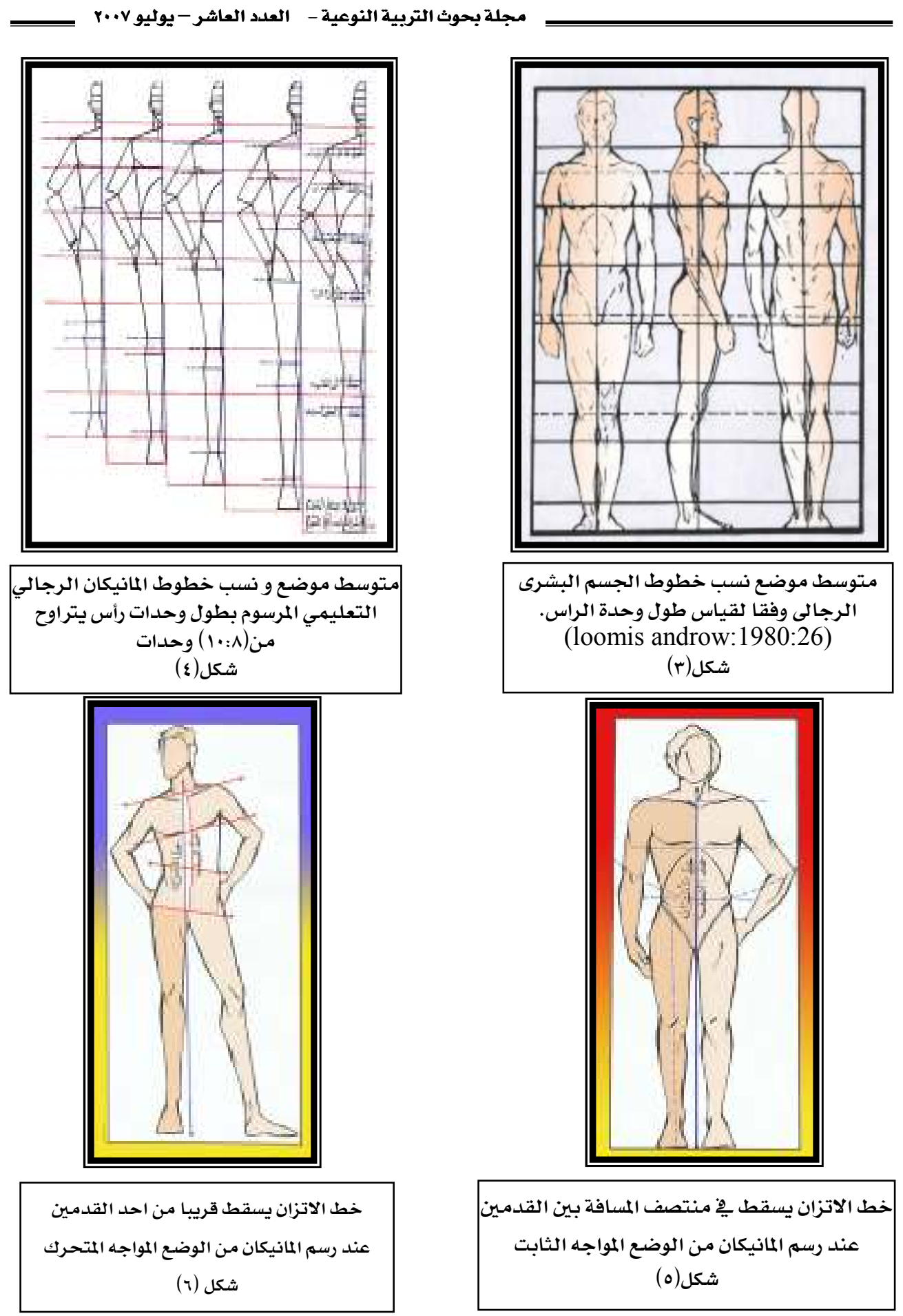




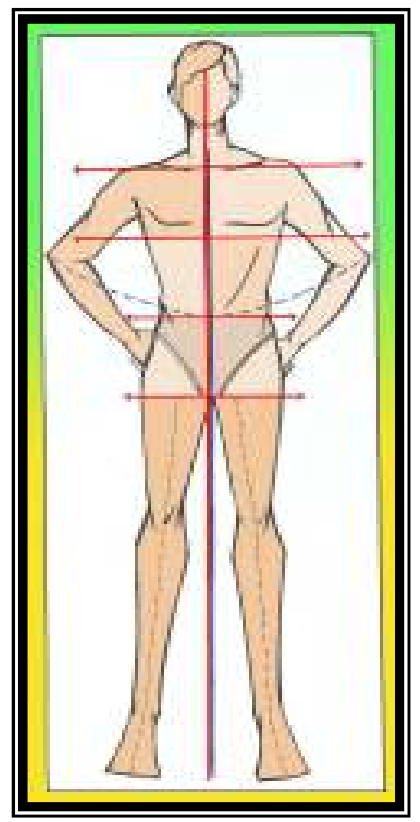
خط النصف يقسم المانيكان إلى جزئين متماثلين يِِّ الوضـع المواجه الثابت.

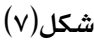
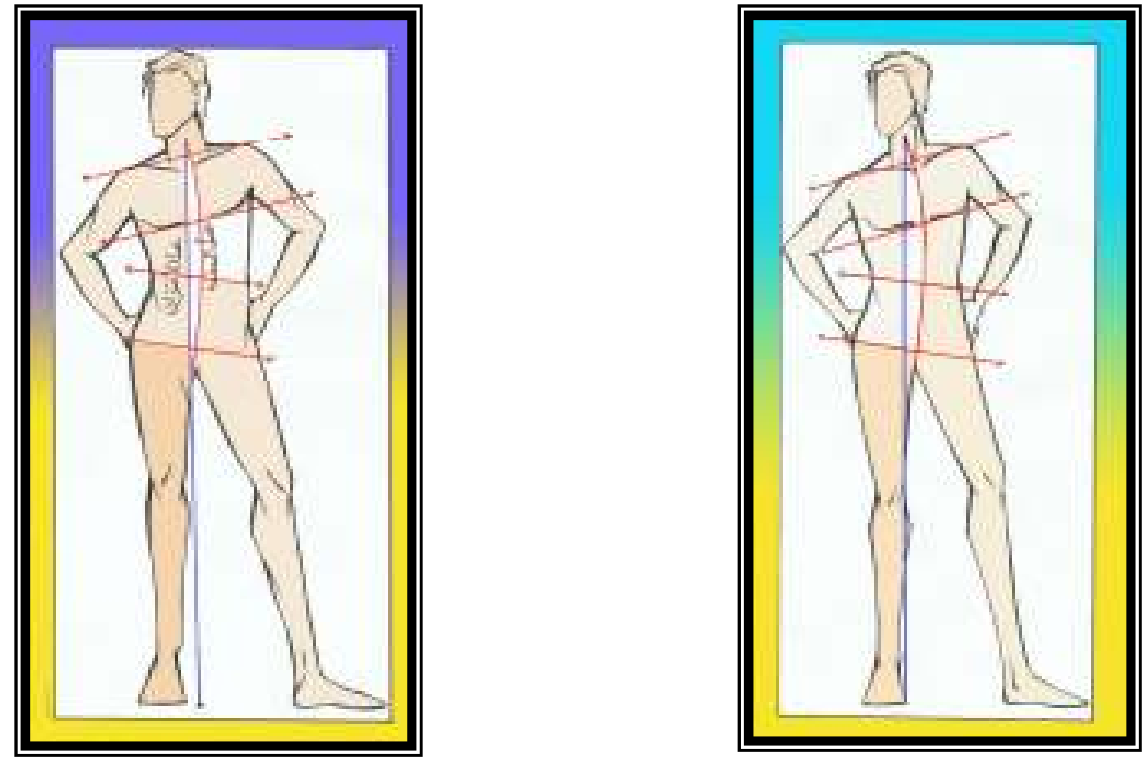

$$
\begin{aligned}
& \text { العلاقة بين مقدار بعد خط نصف المانيكان عن خط الاتزان ودرجة زاوية ميل كل من }
\end{aligned}
$$

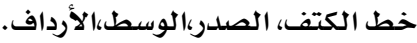

$$
\begin{aligned}
& \text { (شكلم أ،ب) }
\end{aligned}
$$




\section{المراجع

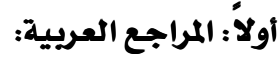

ا- أحمد حامـد منصور :"الفيديو وتأثيره يْ عمليـة التعليهم والتعلهم"، ندوه قادة التقنيـات التربويـة، المركز

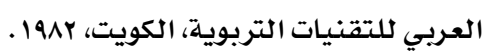

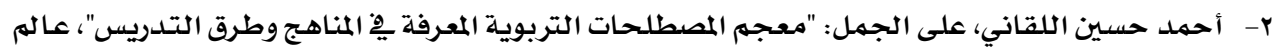

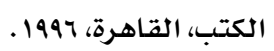

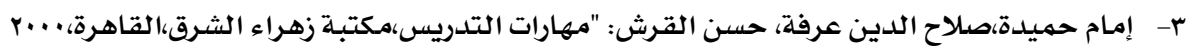

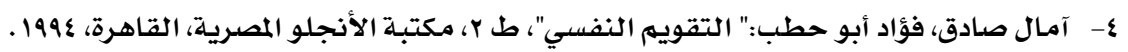

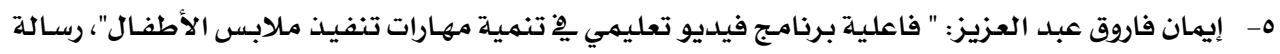

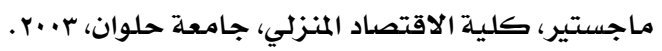

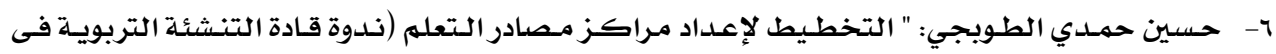

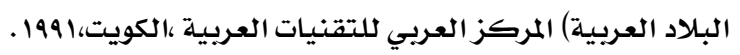

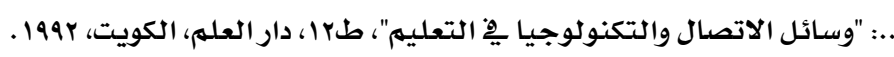

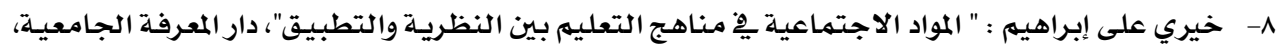

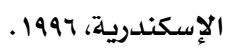

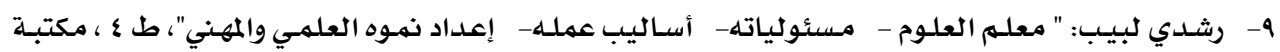

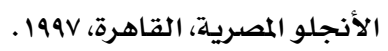

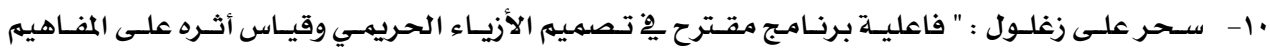

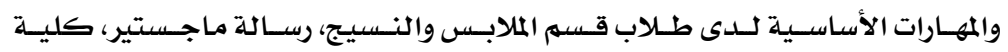

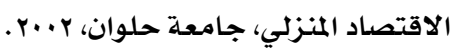

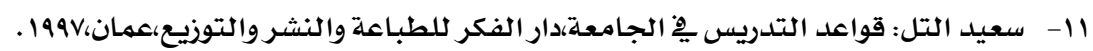

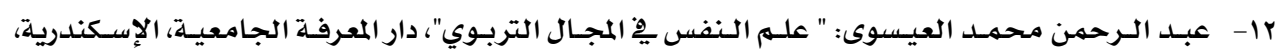
.1997

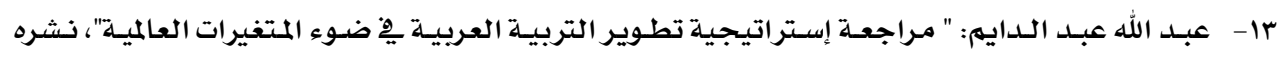

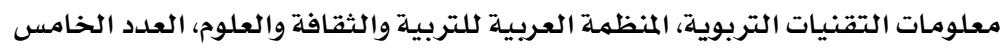

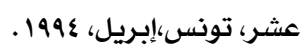

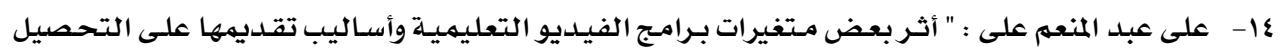

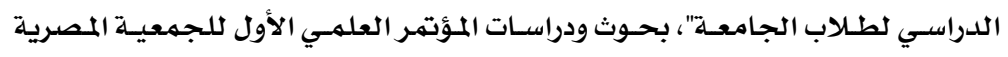

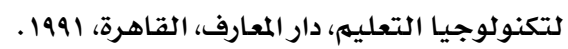

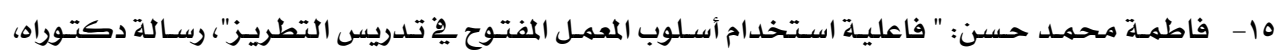

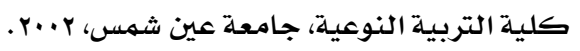

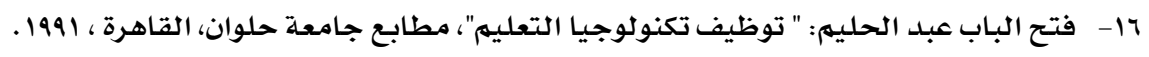

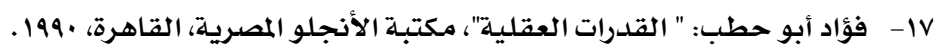

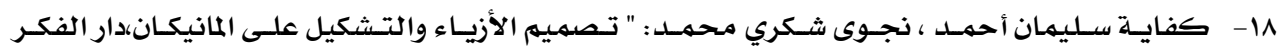

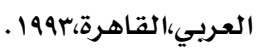




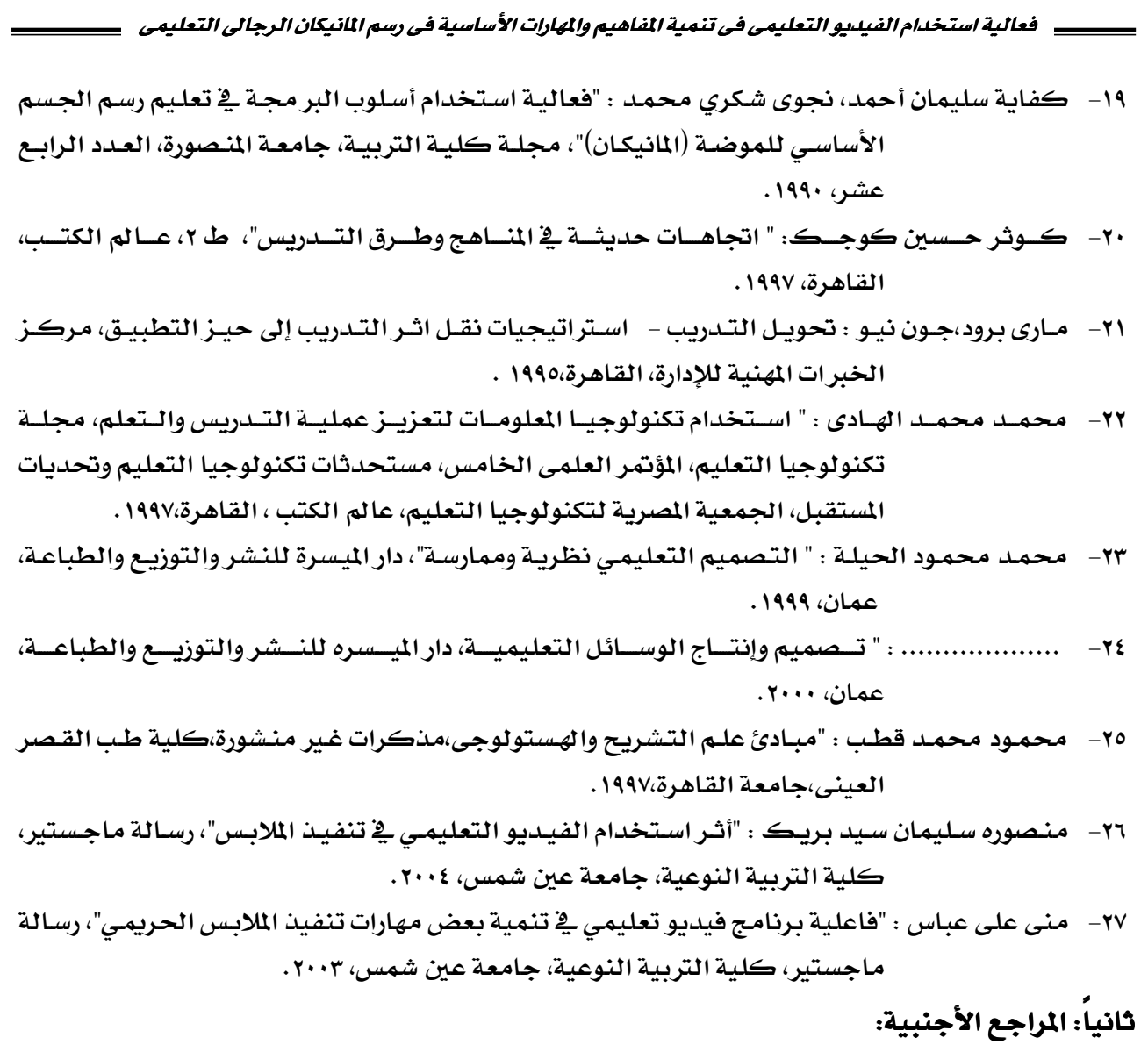

28- Byrgo Fernando :"Figurino Di Moda" Studio Della proporzoni, Techicne di colorazione, Bilingue Italiano publisher's, 2000.

29- David Jucobsen and others : "Methods for teaching, Askill approach", Macmillan publishing company, New York, 1993.

30- Donald kagen :"basic concepts for drawing human body and fashion figure illustration", Virginia poly teaching, institute and university, 2004.

31- Drago Shery :"The comparison of experiential and expository teaching methods in fashion figure Illustraion on among university students (Experiential teaching methods)" volume (54-O8A) of dissertation abs tracts international, P. (2919), 2002.

32-Horten james :“ The beginners guid, human anatomy for artists step by step ”, new Holland ,publishing(uk).,London,2000.

33-Iowa state university : "3D MAN fashion figure drawing program for third grade students", faculty of home economics, iowa state university, 2006. 
34-John Patrick Ireland :"Figure templates”, published by, B.T., Bats ford, Ltd., London, 1997.

35- Loomis Androw :"Figure drawing for all its worth", printed in great Britain, London, 1980.

36-Mabel Erwan :"clothing for modern" macmillan publishers company, New York, 1997.

37-Modest Levira A :"Production and formative evaluation of an instructional video an enlarging images (Aprogramme for teachers in Tanzania)", Dissertation abstracts international, Canada, Ind., Concordia university, 1994, p.p 112-130.

\section{ثالثاً: مواقع الإنترنت:}

38-(http://www. Almahaja. com/ jackafat_tanmia_tanmia 253.htm.

39-(http://www. Biology.clc.uc.edu/courses/bio105/bone.htm.

40-(http://www. Inner body.com/index.html.

41-(http://www.mkm-haifa.co.il/schools/ almotnbi/ atar2003/ afaf/ skeleton.htm.

42- (http://www.nigeriain fonet.com/human_anatomy.htm.

43-(http://www.shefa-amr.net/item.php

44-(http://www.6abib.com/anatomy/ant-22.htm.

45-(http://www.6abib.com/anatomy/ant-22.htm.

46-(http://www.6abib.com/ask/archive/index.php?t1989.html. 